\title{
Long-term leaching of nutrients and contaminants from wood combustion ashes
}

\author{
Maresca, Alberto; Hyks, J.; Astrup, Thomas Fruergaard
}

Published in:

Waste Management

Link to article, DOI:

10.1016/j.wasman.2017.11.056

Publication date:

2018

Document Version

Peer reviewed version

Link back to DTU Orbit

Citation (APA):

Maresca, A., Hyks, J., \& Astrup, T. F. (2018). Long-term leaching of nutrients and contaminants from wood combustion ashes. Waste Management, 74, 373-383. https://doi.org/10.1016/j.wasman.2017.11.056

\section{General rights}

Copyright and moral rights for the publications made accessible in the public portal are retained by the authors and/or other copyright owners and it is a condition of accessing publications that users recognise and abide by the legal requirements associated with these rights.

- Users may download and print one copy of any publication from the public portal for the purpose of private study or research.

- You may not further distribute the material or use it for any profit-making activity or commercial gain

- You may freely distribute the URL identifying the publication in the public portal

If you believe that this document breaches copyright please contact us providing details, and we will remove access to the work immediately and investigate your claim. 
2 Long-term leaching of nutrients and contaminants from

\section{wood combustion ashes}

4

5

Maresca, A. ${ }^{a}$, Hyks, J. $^{b} \&$ Astrup, T.F. ${ }^{a}$

6

7

8

9 a) Technical University of Denmark, Department of Environmental Engineering, Building 115,

Bygningstorvet, 2800 Kgs. Lyngby, Denmark

b) Danish Waste Solutions ApS, Agern Allé 3, 2970 Hørsholm, Denmark 
With increasing amounts of woody biomass being combusted for energy purposes worldwide, more wood ash is being generated and needs management. As an alternative to landfilling, residues may be utilised for liming and fertilising purposes on forest soils. Comprehensive evaluations of long-term leaching from these residues are needed in order to assess potential environmental impacts associated with their utilisation. Two Danish wood ash samples, one fly ash and one mixed ash (a combination of fly ash and bottom ash), were evaluated in long-term percolation column tests (up to $\mathrm{L} / \mathrm{S} \sim 2000 \mathrm{~L} / \mathrm{kg}$ ), in order to quantify the release of major, minor and trace metal(loid)s. While columns of three different lengths were used, the leaching of individual elements could be described as a function of the L/S ratio irrespective of the column length. At L/S $1000 \mathrm{~L} / \mathrm{kg}$, the cumulative releases of K, S, Na, Ca and Rb were at 40-100\% of their respective solid contents, followed by $\mathrm{Ba}, \mathrm{Cr}, \mathrm{Sb}, \mathrm{Sr}$ and $\mathrm{V}$ at $15-40 \%$ and $\mathrm{Al}, \mathrm{Mg}, \mathrm{Zn}, \mathrm{Cd}, \mathrm{Co}, \mathrm{Fe}, \mathrm{Pb}, \mathrm{Tl}, \mathrm{Mn}$ and $\mathrm{P}$ at $<5 \%$. Speciation calculations indicated that i) the observed concentrations of $\mathrm{Ca}, \mathrm{Mg}, \mathrm{Al}, \mathrm{Ba}, \mathrm{Si}$ and sulphate from both ash types could be described through the dissolution/precipitation of a limited set of minerals and that ii) leaching of silicates should be included in long-term assessment of alkalinity release from wood ashes. Non-equilibrium conditions were indicated by flow interruptions. However, the presence of non-equilibrium did not have significant effect on the calculated cumulative releases at high $\mathrm{L} / \mathrm{S}$ ratios. Based on the assessment of cumulative releases at $\mathrm{L} / \mathrm{S} 10$ $\mathrm{L} / \mathrm{kg}$ and $\mathrm{L} / \mathrm{S} 1000 \mathrm{~L} / \mathrm{kg}$ it is concluded that low L/S-based data may not provide sufficient background for prediction of long-term release from wood ash, in particular for $\mathrm{Ba}, \mathrm{Cr}, \mathrm{Sb}$ and $\mathrm{V}$, and less critically also for $\mathrm{As}, \mathrm{Cd}, \mathrm{Cu}, \mathrm{Mo}$ and $\mathrm{Ni}$.

Keywords: biomass ash; liming; MSWI; flow interruption; geochemical modelling; column

Abbreviations:

ANC: acid neutralisation capacity; DOC: dissolved organic carbon; LOQ: limit of quantification; MSWI: municipal

\section{INTRODUCTION}

The combustion of biomass for energy purposes is expanding worldwide, especially in countries like Denmark (The Danish Council on Climate Change, 2015) with concrete targets for the phase-out of fossil resources. This phase-out often involves the expansion of biomass combustion, with wood as a common energy source. Accordingly, increasing amounts of wood chips or wood pellets are currently being combusted in Denmark for energy purposes, i.e. from 5.7 PJ 
in 2005 to 16 PJ in 2015 (Danish Energy Agency, 2017), leading to the generation of about 22,300 metric tons dry weight of wood ash in 2012 (Skov and Ingerslev, 2013).

Instead of landfilling, wood ash utilisation on top of forest and agricultural soils has been seen as a more sustainable solution - which would utilise the ash liming potential (e.g. Huang et al., 1992; Meiwes, 1995; Pitman, 2006) and recirculate primary plant nutrients (N, P and K) present in these materials. Nevertheless, as wood ash application may lead to soil/water contamination if high levels of toxic elements are released, wood ash application has been regulated in many European countries (e.g. Denmark, Finland, Sweden, Austria and Germany) by setting limits for maximum dosages and threshold values for "heavy metals", as well as by providing guidelines for wood ash application. To ensure meaningfulness of such guidelines and to evaluate potential benefits/risks associated with the utilisation of wood ash on soils, a comprehensive characterisation of the long-term release of nutrients, liming components and environmentally problematic elements is needed, also with regards to leaching mechanisms. ashes are typically generated: bottom ash, fly ash and mixed ash (combination of fly ash and bottom ash). The composition of the different types of wood ash has been investigated in the past (e.g. Ingerslev et al., 2011; Maresca et al., 2017) together with the impact of different fuel types (e.g. Reimann et al., 2008; Werkelin et al., 2011), combustion technologies (e.g. Drift et al., 2001; Freire et al., 2015) and boiler operating parameters (e.g. Demeyer et al., 2001; Misra et al., 1993). Overall, $\mathrm{Ca}, \mathrm{K}$ and $\mathrm{Si}$ are the most abundant elements $\left(10^{4}-10^{5} \mathrm{mg} / \mathrm{kg}\right)$, followed by $\mathrm{Mg}, \mathrm{P}, \mathrm{Na}, \mathrm{Fe}$, 
Larsson and Westling, 1998; Ludwig et al., 2005; Steenari et al., 1999a, 1999b; Steenari and Karlfeldt Fedje, 2010), rather than column leaching experiments (e.g. Eriksson, 1996; Liodakis et al., 2009). Similar to the characterization of the short-term leaching, the impact of different ash types, treatments (e.g. granulated and pelletised ash, with or without additives) and wood fuel types have been investigated. Both distilled water and acidified distilled water (with e.g. HCl, $\mathrm{HNO}_{3}$ or $\mathrm{H}_{2} \mathrm{SO}_{4}$ ) were used (Larsson and Westling, 1998; Ludwig et al., 2005; Steenari et al., 1999b). L/S ratio used in the batch test studies varied between $16 \mathrm{~L} / \mathrm{kg}$ and $60,000 \mathrm{~L} / \mathrm{kg}$ - thirty steps at $2000 \mathrm{~L} / \mathrm{kg}$ (e.g. Larsson and Westling, 1998; Steenari and Karlfeldt Fedje, 2010). In addition, many studies focused on the release of major elements (e.g. Ca, $\mathrm{K}, \mathrm{Mg}, \mathrm{Na}$ and sulphate), whilst trace elements were often overlooked. Some studies have focused on fresh ashes, others on aged (carbonated, hardened) ashes. Overall, the wide range of different test parameters (e.g. ash type, leachant, L/S ratio, investigated elements and pre-treatments) makes direct comparison of the results difficult. Although geochemical speciation modelling has been used to describe potential mechanisms controlling the release from MSWI ash (e.g. Astrup et al., 2006; Dijkstra et al., 2002; Meima and Comans, 1999), to our knowledge, only few studies applied geochemical modelling on a wide range of elements in wood ash leachates (Maresca et al., 2017; Steenari et al., 1999a) and wood gasification ashes (Allegrini et al., 2011; van der Sloot and van Zomeren, 2010). However, none of these studies addressed long-term leaching by means of a column leaching experiments. Evaluating the leaching mechanisms from fresh ashes may provide a consistent and relevant baseline, which is needed for identifying the effects of ageing of ashes in the field. So far such an evaluation has not been provided for a wide range of elements and at the high $\mathrm{L} / \mathrm{S}$ ratios.

The aim of this paper is: i) to systematically assess the release of nutrients and elements of possible environmental concern from fresh wood ashes by means of long-term percolation tests; ii) to evaluate equilibrium conditions during the columns leaching experiments and to identify mineral phases which may control the leaching of nutrients and trace metal(loid)s; iii) to estimate the long-term cumulative release of nutrients, trace metal(loid)s and alkalinity from wood ash; and iv) to compare the long-term releases with the releases obtained at low L/S ratios.

\section{MATERIALS AND METHODS}

\subsection{Sampling and material handling}

Fresh combustion ashes were sampled directly from the ash discharge unit at two grate-fired combustion plants in Denmark, which use wood chips as fuel (mainly from Picea abies). One fly ash sample (FA) and one mixed ash sample 

hermetically closed buckets at $10^{\circ} \mathrm{C}$ prior to further use.

\subsection{Ash characterisation}

112 The chemical composition of MA and FA was investigated in Maresca et al. (2017) with the references "MA-9c" and

113 "FA-2b", respectively. Section S1, in Supplementary Material, provides a summary of the methodology used by

114 Maresca et al. (2017) for characterising MA and FA, while Table 1 shows the overall composition of these wood ash

115 samples. In general, the content of major, minor and trace elements in both MA and FA fell within typical ranges reported in other wood ash studies - see Maresca et al. (2017) and therein literature.

\subsection{Up-flow percolation experiments}

119 Two types of column leaching experiments were carried out for MA and FA: a continuous column leaching experiment and a flow-interrupted column leaching experiment. In both cases, MA and FA were sieved prior to packing the columns and particles $>4 \mathrm{~mm}$ were crushed in a jaw crusher. Table 2 provides an overview of the individual columns.

\subsubsection{Continuous columns}

The continuous column leaching experiments were based on EN 14405: 2017. For both MA and FA three columns (acrylic glass; $\varnothing: 5 \mathrm{~cm}$ ) of different lengths were used: "long” (referred to as MA-L and FA-L), "medium" (MA-M and FA-M) and "short" (MA-S and FA-S). A thin layer $(1.5 \mathrm{~cm})$ of acid-washed sand was placed at the top and bottom of all columns, together with nylon filters (PA 6.6; mesh opening: $20 \mu \mathrm{m}$ ) used to prevent transport of particles into the adjacent tubing.

The columns were equilibrated with distilled water for three days via continuous recirculation of the leachate

131 (EN 14405: 2017). Thereafter, an average flow rate of $12 \pm 1 \mathrm{~mL} / \mathrm{h}$ was maintained for the entire duration of the experiment ( $\sim 5$ months). The entire mass of leachate coming from each column was collected by means of PE bottles of

133 different volumes. At relatively low cumulative $\mathrm{L} / \mathrm{S}$ ratios about $50-100 \mathrm{~mL}$ of leachate was collected per bottle,

134 whereas at higher cumulative $\mathrm{L} / \mathrm{S}$ ratios about $250-1000 \mathrm{~mL}$ of leachate was collected per bottle. The weight of all

135 bottles was recorded to keep track of the cumulative volume of the leachate; $\mathrm{pH}$ and conductivity were measured in all 
bottles. Chemical analysis of leachate was carried out for a selected number of samples. The samples were filtered

(PTFE filters; mesh opening: $0.45 \mu \mathrm{m}$ ) and divided into two fractions. The first fraction was acidified to $\mathrm{pH}<2$ concentration of dissolved organic carbon (DOC) and dissolved total carbon using a carbon analyser, whereas chloride, sulphate, nitrate and bromide were determined by ion chromatography. L/S ratio (see Section 3.1.1 and 3.1.2). Concentrations below the actual limit of quantification (LOQ) were assumed equal to the LOQ (i.e. potential overestimation).

\subsubsection{Flow-interrupted columns}

The presence and impact of possible non-equilibrium conditions on the leaching from MA-L and FA-L were investigated by means of flow interruptions. These were carried out in two additional columns identical to the -L columns in terms of design, packing, operation and leachate sampling and treatment: MA-L_FI and FA-L_FI. Two sets of flow interruptions were carried out, in either system, at L/S $2 \mathrm{~L} / \mathrm{kg}$ and L/S $50 \mathrm{~L} / \mathrm{kg}$, to reflect conditions typical for short- and long-term leaching, respectively. Following the approach of Hyks et al. (2009) - who observed leachate concentrations to approach equilibrium during a one-month long period of flow interruptions in columns packed with MSWI bottom ash - each flow interruption set was designed with the intention of collecting four leachate samples with cumulative retention times ranging from one to four weeks. More specifically, during each flow interruption set, the inlet column flow was stopped and the system was left undisturbed for seven days. The flow was then restarted and a leachate volume corresponding to $1 / 4$ of the estimated pore volume was collected from the outlet - pore volume of each

\subsection{Geochemical modelling}

162 Solution speciation of leachates from both continuous columns and flow-interrupted columns were used as inputs for speciation modelling using the ORCHESTRA code (Meeussen, 2003). DOC complexation was included, using the 
165 Activity coefficients were calculated based on the Davies equation, and oxidising conditions $(\mathrm{pH}+\mathrm{pE}=15)$ were assumed during speciation calculations. Thermodynamic data from the modified MINTEQA2 thermodynamic database (see Butera et al., 2015) were used.

"Plausible" minerals, potentially controlling the solution concentrations of different elements, were selected based on their calculated saturation indices (SIs). The full list of identified minerals is provided in Table S1. Theoretical leachate concentrations in equilibrium with the selected minerals were modelled based on the approach suggested by Astrup et al. (2006) and compared with the observed concentrations. The minerals most likely controlling leaching were identified based on proximity between theoretical and observed concentration curves. Finally, the list of "plausible" minerals was compared with findings in the existing literature and the results of previous XRD scanning carried out for the ashes investigated here (see Maresca et al., 2017).

The cumulative release of alkalinity was calculated from the solution speciation. Two types of alkalinity were considered: standard and total. Standard alkalinity was calculated as St.Alk. $=2\left[\mathrm{CO}_{3}{ }^{2-}\right]+\left[\mathrm{HCO}_{3}{ }^{-}\right]+\left[\mathrm{OH}^{-}\right]$, where the square brackets represent the molar concentration of the different species. Total alkalinity included other possibly relevant solution species: Tot.Alk $=$ St.Alk. $+2\left[\mathrm{PO}_{4}{ }^{3-}\right]+\left[\mathrm{HPO}_{4}{ }^{2-}\right]+\left[\mathrm{SiO}(\mathrm{OH})_{3}{ }^{-}\right]-\left[\mathrm{H}^{+}\right]-\left[\mathrm{HSO}_{4}{ }^{-}\right]$.

\section{RESULTS AND DISCUSSION}

\section{$181 \quad 3.1$ Continuous columns}

Since MA and FA had significantly different moisture content, different amounts of either material were packed in the columns, which in turn reached rather different cumulative L/S ratios during the course of the leaching experiment (see Table 2). In general, similar concentration levels were observed when comparing the analytical concentrations and the modelled results of $-\mathrm{S},-\mathrm{M}$ and -L columns against each other (within the same ash sample) as a function of the L/S ratio. Therefore, the observed leachate compositions and speciation results will be described as a function of the L/S ratio, rather than being discussed separately for each individual column.

Figures 1 and S1 report the results from continuous columns in terms of cumulative releases, whereas Figure 2 compares the observed composition of the leachates with the results from speciation calculations for -S columns (Figure S2 and S3 do it for -L columns). The rationale for selecting specific elements to be shown in the main text, rather than in the Supplementary Material, is to report a representative number of major, minor and trace elements, characteristic of different leaching behaviours (e.g. availability or solubility controlled) and adequate fit with the modelled concentrations, and does not affect the way the individual elements are described in the following text. 


\subsection{1 pH and major elements}

198 Both materials showed decreasing leachate $\mathrm{pH}$, from the initial value of 12.5 to 10.9 at L/S $1000 \mathrm{~L} / \mathrm{kg}$ (further decreasing by about half of a unit in the FA column at L/S $2300 \mathrm{~L} / \mathrm{kg}$ ). The $\mathrm{pH}$ decrease in FA leachates was a little slower compared to the MA leachates, which reflected the higher ANC of FA relative to MA (i.e. $\mathrm{ANC}_{4.5}=13$ meq $\mathrm{H}^{+} / \mathrm{g}$ for FA and 5.3 meq $\mathrm{H}^{+} / \mathrm{g}$ for MA; see Maresca et al., 2017).

For K, Na, S and chloride (and $\mathrm{Rb}$ ), a relatively fast initial washout was observed for both MA and FA. The solution concentrations of these elements decreased by two to three orders of magnitude before $\mathrm{L} / \mathrm{S} 2 \mathrm{~L} / \mathrm{kg}$ and $\mathrm{L} / \mathrm{S} 10$ $\mathrm{L} / \mathrm{kg}$ for MA and FA, respectively (see Figures 1 and S1). A rapid decrease in the electrical conductivity was observed as well (Figure S1). Similar leaching behaviours and concentration levels were reported by Freire et al. (2015), Holmberg et al. (2000) and Supancic et al. (2014), despite their use of different types of leaching tests. Based on the observed trends, the initial leaching of K, Na and chloride appeared to be linked to dissolution of readily soluble salts (e.g. $\mathrm{NaCl}, \mathrm{KCl}$ ), whereas the solution concentration of $\mathrm{S}$ (and $\mathrm{Ba}$ ) could be explained by dissolution/precipitation of barite before L/S $10 \mathrm{~L} / \mathrm{kg}$ for MA and before L/S $100 \mathrm{~L} / \mathrm{kg}$ for FA. At higher L/S ratios, no mineral was found in the database which could be used to explain the observed low concentrations of S (and Ba).

Relatively large amounts of Ca were released before the L/S $50 \mathrm{~L} / \mathrm{kg}$ for MA $(\sim 30 \mathrm{~g} / \mathrm{kg})$ and before L/S 50 $\mathrm{L} / \mathrm{kg}$ for FA ( $90 \mathrm{mg} / \mathrm{kg}$ ); later releases were gentler as indicated by the cumulative release curve (Figure 1). At $\mathrm{L} / \mathrm{S}$ $1000 \mathrm{~L} / \mathrm{kg}$ the cumulative release of Ca corresponded to about $40-43 \%$ of the ashes' total Ca content. Similar trends were reported by Steenari et al. (1999b) during sequential batch leaching tests. The calculated SIs suggested that Ca release from MA columns was controlled by calcite and calcium silicate hydrates (such as jennite) over most of the L/S range investigated here. At the same time, hilgenstokite and merwinite also provided an adequate description of the observed Ca concentrations at $\mathrm{L} / \mathrm{S}<50 \mathrm{~L} / \mathrm{kg}$, whereas Ca levels at $\mathrm{L} / \mathrm{S}<2 \mathrm{~L} / \mathrm{kg}$ appeared to be controlled by portlandite. For the FA columns, jennite, tobermorite, calcite and hilgenstokite could be used to explain the observed Ca concentrations until L/S $100 \mathrm{~L} / \mathrm{kg}$, whereas portlandite and merwinite seemed important at $\mathrm{L} / \mathrm{S}$ below $20 \mathrm{~L} / \mathrm{kg}$. In comparison with the total contents in the ashes, the release of $\mathrm{Al}$ and $\mathrm{Mg}$ was observed to be low, but steady (except for the increasing Mg releases at L/S above $1500 \mathrm{~L} / \mathrm{kg}$ for FA) - see Figures 1 and S1. Similar results have been reported by other wood ash studies, despite the different operating conditions and L/S ratios therein used (Freire et al., 
2015; Holmberg et al., 2000; Steenari and Karlfeldt Fedje, 2010; Supancic et al., 2014; van der Sloot and van Zomeren, 2010). SIs calculated for MA leachates suggested hydrotalcite as the main phase controlling the leaching of Mg while also brucite, clinoenstatite and forsterite could be used to explain solution concentrations at $\mathrm{L} / \mathrm{S}>50 \mathrm{~L} / \mathrm{kg}$. Al concentrations could also be controlled by hydrotalcite, albeit only until L/S 100-250 L/kg (visible only for -L and -M column leachates), whereas diaspore appeared more likely to control $\mathrm{Al}$ at higher L/S ratios. With regard to FA leachates, $\mathrm{Mg}$ concentrations could be described adequately by åkermanite at L/S ratios below $20 \mathrm{~L} / \mathrm{kg}$, while åkermanite, brucite, forsterite and clinoenstatite were found relevant at higher L/S ratios. Tricalcium aluminate hydrate provided an adequate description of the observed $\mathrm{Al}$ trends in the $-\mathrm{L}$ and $-\mathrm{M}$ column leachates until $\mathrm{L} / \mathrm{S} 150 \mathrm{~L} / \mathrm{kg}$, but modelled values overestimated the observed concentrations by one to two orders of magnitude; at the higher L/S ratios, modelled concentrations for diaspore slowly approached the observed $\mathrm{Al}$ concentrations.

The release of Si increased rapidly after the L/S $200 \mathrm{~L} / \mathrm{kg}$ and cumulative releases of about $12 \mathrm{~g} / \mathrm{kg}$ were observed by the L/S $1000 \mathrm{~L} / \mathrm{kg}$ for both MA and FA ashes (corresponding to $4.7 \%$ and $9.7 \%$ of the total Si content in MA and FA ashes, respectively) - further increasing up to $\sim 21 \mathrm{~g} / \mathrm{kg}$ in the case of FA ashes at L/S $2300 \mathrm{~L} / \mathrm{kg}$. Si concentrations corresponded well with the solubility of the same silicates mentioned for $\mathrm{Ca}$ and $\mathrm{Mg}$, i.e. jennite (L/S 0$500 \mathrm{~L} / \mathrm{kg}$ ), clinoenstatite (L/S 50-1000 L/kg), merwinite (L/S 0-50 L/kg) and possibly also wollastonite (L/S 500-1000 $\mathrm{L} / \mathrm{kg}$ ) for the MA columns. In the FA columns, tobermorite appeared adequate to describe Si concentrations across the entire L/S range, while clinoenstatite also provided a good description of the observed Si concentrations. Again, åkermanite, jennite, merwinite and wollastonite were identified as plausible mineral phases, albeit constrained to limited $\mathrm{L} / \mathrm{S}$ intervals.

P concentrations were generally below LOQ $(<20 \mu \mathrm{g} / \mathrm{L})$ except for the very initial leachates $(\mathrm{L} / \mathrm{S}<2 \mathrm{~L} / \mathrm{kg})$, where concentrations up to $80 \mu \mathrm{g} / \mathrm{L}$ and $37 \mu \mathrm{g} / \mathrm{L}$ were found for FA and MA, respectively. Likewise, Freire et al. (2015), Maresca et al. (2017) and Supancic et al. (2014) reported concentration levels of P below LOQ in their L/S 10 $\mathrm{L} / \mathrm{kg}$ batch tests. Hilgenstockite, a tetracalcium phosphate (structurally similar yet more soluble than apatite minerals) found in P-rich slag, could explain the measured P concentrations before they decreased below LOQ.

Fe concentrations were mostly found below LOQ $(<1.3 \mu \mathrm{g} / \mathrm{L})$ except for the initial release (i.e. before the L/S $1 \mathrm{~L} / \mathrm{kg}$ for MA columns and L/S $5 \mathrm{~L} / \mathrm{kg}$ for FA columns) showing concentrations up to $20 \mu \mathrm{g} / \mathrm{L}$. Low leaching of Fe is likely caused by precipitation of $\mathrm{FeO}(\mathrm{OH})$, such as lepidocrocite or goethite.

Overall, the results of speciation calculations were found to be in general agreement with (i) results of X-ray diffraction analyses of MA and FA ashes (Maresca et al., 2017), (ii) results of independent speciation modelling carried 
out for leachates from pH-dependent tests of MA and FA ashes (Maresca et al., 2017), (iii) information found in the literature by other wood ash studies (Dahl et al., 2010; Freire et al., 2015; Holmberg and Claesson, 2001; Magdziarz et al., 2016; van der Sloot and van Zomeren, 2010; Vassilev et al., 2013a) and (iv) previous geochemical modelling calculations carried out for MSWI ash (Astrup et al., 2006; Hyks et al., 2011, 2009a; Meima and Comans, 1997; Sabbas et al., 2003). Furthermore, mineral solubility played an important role in the release of major elements from the wood

\subsubsection{Trace elements and DOC}

260 Concentrations of several trace metals were below LOQ already at the very beginning of the column test (LOQ: 0.26 $261 \mu \mathrm{g} / \mathrm{L}$ for As; $3.8 \mu \mathrm{g} / \mathrm{L}$ for Be; $0.20 \mu \mathrm{g} / \mathrm{L}$ for $\mathrm{Cd} ; 0.045 \mu \mathrm{g} / \mathrm{L}$ for $\mathrm{Co} ; 7.0 \mu \mathrm{g} / \mathrm{l}$ for $\mathrm{Cu} ; 1.3 \mu \mathrm{g} / \mathrm{L}$ for Fe; $28 \mu \mathrm{g} / \mathrm{L}$ for Li; 5.9 $262 \mu \mathrm{g} / \mathrm{L}$ for Mo; $4.4 \mu \mathrm{g} / \mathrm{L}$ for $\mathrm{Ni}$; and $0.017 \mu \mathrm{g} / \mathrm{L}$ for $\mathrm{Tl}$ ), except for some releases during the initial washout below $\mathrm{L} / \mathrm{S} 2$ $263 \mathrm{~L} / \mathrm{kg}$. These overall trends were observed for all columns except FA-S in the case of Co, $\mathrm{Ni}$ and $\mathrm{Tl}$, where slightly 264 higher releases were found - see Figure S1.

The initial leaching of DOC decreased rapidly by one order of magnitude from $17 \mathrm{mg} / \mathrm{L}$ for MA and $65 \mathrm{mg} / \mathrm{L}$ for FA at L/S $5 \mathrm{~L} / \mathrm{kg}$, and then stabilised at $0.2-0.5 \mathrm{mg} / \mathrm{L}$. Very low levels of DOC resulted in a limited impact of DOC$\mathrm{Cu}$ complexation; in fact, only about 6-14\% of the dissolved $\mathrm{Cu}$ was calculated to be complexed with DOC. Although $\mathrm{Cu}(\mathrm{OH})_{2}$ has been suggested for controlling $\mathrm{Cu}$ leaching in MSWI ashes (Dijkstra et al., 2006; Komonweeraket et al., 2015), $\mathrm{Cu}(\mathrm{OH})_{2}$ was calculated to be undersaturated by two orders of magnitude.

The majority of $\mathrm{Pb}$ was released before reaching $\mathrm{L} / \mathrm{S} 20 \mathrm{~L} / \mathrm{kg}$ for MA $(\sim 0.06 \mathrm{mg} / \mathrm{kg})$ and $\mathrm{L} / \mathrm{S} 150 \mathrm{~L} / \mathrm{kg}$ for FA ( $\sim 0.5 \mathrm{mg} / \mathrm{kg}$ ), but these releases were insignificant compared with the $\mathrm{Pb}$ solid content: $13.8 \mathrm{mg} / \mathrm{kg}$ in MA and 55.3 $\mathrm{mg} / \mathrm{kg}$ in FA. Similarly, low releases of Pb have generally been reported by other wood ash studies (Freire et al., 2015; Pöykiö et al., 2009; Supancic et al., 2014). While no significant complexation between DOC and Pb was identified, inorganic complexation with hydroxyl - and to a much lower extent chloride ions was suggested by the speciation calculations during the initial washout of $\mathrm{Pb}$ (before the $\mathrm{L} / \mathrm{S} 10 \mathrm{~L} / \mathrm{kg})$. After this, $\mathrm{Pb}$ concentrations in MA leachates $(\sim 2$ $\mu \mathrm{g} / \mathrm{L})$ slowly approached LOQ levels by the L/S $30 \mathrm{~L} / \mathrm{kg}$. On the contrary, stable Pb levels ( $5 \mu \mathrm{g} / \mathrm{L})$ in FA leachates would point either to sorption controlled leaching and/or mineral solubility control (e.g. apatite-like minerals) before $\mathrm{L} / \mathrm{S} 50 \mathrm{~L} / \mathrm{kg}$. Afterwards, the Pb solution concentration decreased to LOQ levels by the L/S $150-200 \mathrm{~L} / \mathrm{kg}$ indicating mineral depletion. 
The release of $\mathrm{Cr}$ differed considerably between the two ashes, yielding to relatively large differences in the calculated cumulative releases: MA ashes released $\mathrm{Cr}$ very slowly during the entire duration of the column experiment $282(\sim 1 \mathrm{mg} / \mathrm{kg}$ at L/S $1000 \mathrm{~L} / \mathrm{kg})$, whereas FA ashes showed a rapid release of $\mathrm{Cr}$ by the cumulative $\mathrm{L} / \mathrm{S} 200 \mathrm{~L} / \mathrm{kg}(\sim 9$ $\mathrm{mg} / \mathrm{kg}$ ) followed by a slower releasing rate $(\sim 13 \mathrm{mg} / \mathrm{kg}$ at the cumulative $\mathrm{L} / \mathrm{S} 2300 \mathrm{~L} / \mathrm{kg})$. Other wood ash-leaching studies have generally measured Cr levels in L/S $10 \mathrm{~L} / \mathrm{kg}$ batch tests, reporting levels anywhere between $<0.5 \mathrm{mg} / \mathrm{kg}$ and $\sim 10 \mathrm{mg} / \mathrm{kg}$ (Freire et al., 2015; Ludwig et al., 2005; Supancic et al., 2014). While the use of $\mathrm{BaCrO}_{4}$ or $\mathrm{Ba}(\mathrm{S}, \mathrm{Cr}) \mathrm{O}_{4}$ solid solution has been widely proposed in literature to describe the leaching of $\mathrm{Cr}$ from alkaline solid wastes, namely MSWI air-pollution control residues, steel slag and fossil fuel combustion ashes (Cornelis et al., 2008), in this study both minerals were strongly undersaturated.

The leaching of Sb was low, but steady and corresponded to respectively $20 \%$ and $18 \%$ of the Sb content in MA and FA ashes being released at the cumulative $\mathrm{L} / \mathrm{S} 1000 \mathrm{~L} / \mathrm{kg}$. A similar leaching behaviour was observed for V, which cumulative release at L/S $1000 \mathrm{~L} / \mathrm{kg}$ corresponded to about $30 \%$ and $23 \%$ of the total V content for MA and FA, respectively. The observed concentration levels of $\mathrm{Sb}$ and $\mathrm{V}$ were in overall agreement with the levels reported by other wood ash studies, at comparable L/S ratios (see Pöykiö et al., 2009; Supancic et al., 2014; van der Sloot and van Zomeren, 2010). No suitable mineral with the potential to describe Sb and V concentration levels were found, as all minerals in the database containing $\mathrm{Sb}$ and $\mathrm{V}$ were calculated to be strongly undersaturated. It should be noted, however, that at alkaline conditions, oxyanions can substitute other major anions in many different solid solutions for which the thermodynamic data are scarce.

Zn was mostly released before the $\mathrm{L} / \mathrm{S} 30 \mathrm{~L} / \mathrm{kg}$ for MA ash $(1.3-3.0 \mathrm{mg} / \mathrm{kg})$ and $\mathrm{L} / \mathrm{S} 100 \mathrm{~L} / \mathrm{kg}$ for FA ash (1.3$4.0 \mathrm{mg} / \mathrm{kg})$, after which concentrations below LOQ $(1.8 \mu \mathrm{g} / \mathrm{L})$ were generally observed. In the literature, both low releases as well as higher releases can be found, i.e. $<0.2-51 \mathrm{mg} / \mathrm{kg}$ at L/S $10 \mathrm{~L} / \mathrm{kg}$ (Freire et al., 2015; Pöykiö et al., 2009; Supancic et al., 2014). While zincite dissolution has sometimes been proposed to describe $\mathrm{Zn}$ leaching from MSWI ashes (e.g. Astrup et al., 2006; Hyks et al., 2009b), in this study modelled concentrations for zincite overestimated the observed concentrations by about two to three orders of magnitude. Though inconclusive, the lack of fit suggested the occurrence of other processes such as surface complexation or surface precipitation onto other wood ash phases - similarly to what was supposed by Polettini and Pomi (2004) for MSWI bottom ashes.

Sr was released rapidly before the $\mathrm{L} / \mathrm{S} 50 \mathrm{~L} / \mathrm{kg}(\sim 120 \mathrm{mg} / \mathrm{kg}$ for MA ash and $\sim 180 \mathrm{mg} / \mathrm{kg}$ for FA ash), and then more slowly by the end of the column experiment. While all the minerals containing $\mathrm{Sr}$ were somewhat undersaturated, 
differences in the concentration levels in the range of one to two orders of magnitude. The potential formation of new solid solutions, less soluble than the ones available in the database, may have contributed to the lower observed

311 leaching of Sr. It is noteworthy that the same, or structurally similar, minerals were indicated also by Astrup et al.

312 (2006) and Hyks et al. (2009b) to describe the leaching of Sr from MSWI ashes.

With regard to Mo, except for the initial washout at $\mathrm{L} / \mathrm{S} 5 \mathrm{~L} / \mathrm{kg}$ for MA $(0.3 \mathrm{mg} / \mathrm{kg})$ and $\mathrm{L} / \mathrm{S} 20$ for FA ash (1.4

$314 \mathrm{mg} / \mathrm{kg}$ ), all other leachate samples presented Mo concentrations below LOQ. Ni concentrations were observed always 315 below LOQ levels $(4.4 \mu \mathrm{g} / \mathrm{L})$ in MA leachates; FA columns showed a rapid washout of Ni before the $\mathrm{L} / \mathrm{S} 1 \mathrm{~L} / \mathrm{kg}$ in the $316 \mathrm{~L}$ and $-\mathrm{M}$ columns, whereas the $-\mathrm{S}$ column showed a slight increase in concentration until the L/S $100 \mathrm{~L} / \mathrm{kg}(20 \mu \mathrm{g} / \mathrm{L})$, 317 followed by a slow decrease until the L/S $250 \mathrm{~L} / \mathrm{kg}$ (LOQ levels).

318 Overall, relatively large differences were observed between cumulative releases at L/S $10 \mathrm{~L} / \mathrm{kg}$ and L/S 1000 $319 \mathrm{~L} / \mathrm{kg}$, especially for $\mathrm{Ba}, \mathrm{Sb}, \mathrm{V}$ and $\mathrm{Cr}$ (see Table 3); in the case of $\mathrm{As}, \mathrm{Cd}, \mathrm{Cu}, \mathrm{Mo}$ and Ni differences could not be 320 quantified accurately because their concentrations were observed below LOQ in many leachate samples. These results 321 indicated that considerable underestimations can occur if $\mathrm{L} / \mathrm{S} 10 \mathrm{~L} / \mathrm{kg}$ releases are used to estimate long-term releases. While our leaching results were observed to be similar to observations reported in the literature, e.g. generally lower levels at higher L/S ratios, our column experiments however illustrated different behaviours for some elements, in particular $\mathrm{Cr}, \mathrm{Sb}, \mathrm{V}$ and $\mathrm{Sr}$, which demonstrates that (sequential) batch tests may not be sufficient to capture developments in leaching from a long-term perspective. With regards to the leaching mechanisms, mineral dissolution played an important role in the release of trace elements, but other processes with the potential to affect the solution concentration of these elements, such as complexation with both organic and inorganic species, surface complexation onto other wood ash phases and formation of solid solutions, were likely to occur, too.

\section{<Table 3>}

\subsubsection{Potential effects of ageing}

It is noteworthy that while the results of this study provide a consistent characterization of the leaching properties of wood ashes, some limitations may exist when attempting to extend the cumulative release data to wood ash application scenarios - where the ashes, over time, will be subjected to aging reactions alongside with leaching. Studies of other combustion ashes may provide indications of whether the cumulative releases from this study over- or underestimate the release from aged wood ashes: ageing of MSWI ashes has been documented to increase leaching of oxyanions such as $\mathrm{As}, \mathrm{Cr}$, Mo, and $\mathrm{V}$, while leaching of cationic elements such as $\mathrm{Pb}, \mathrm{Zn}$, and $\mathrm{Cd}$ is generally decreasing (e.g. Sabbas et 

leaching system (e.g. Astrup et al., 2006; Meima and Comans, 1999; Polettini and Pomi, 2004; Steenari and Lindqvist, 340 1997).

The results from speciation calculations provide an evaluation of potential mineral phases in the fresh ashes, which may then be used as basis for evaluating potential changes in mineralogy when the ashes are exposed to air and moisture, i.e. ageing of the ashes. From other wood ash studies, minerals such as carbonates, ettringite, gypsum, hydrated silicates and aluminium-silicate phases can be expected in aged ashes (Holmberg and Claesson, 2001; Steenari and Lindqvist, 1997); however, most of the potential mineral phases identified for the fresh ashes have been suggested also for aged ashes in literature (Gori et al., 2011; Holmberg and Claesson, 2001; Vassilev et al., 2013b).

\subsection{Flow-interrupted columns}

349 A large impact of flow interruptions was observed on the measured $\mathrm{pH}$ as well as solutions concentrations of $\mathrm{Al}, \mathrm{Ba}$, $\mathrm{Ca}, \mathrm{K}, \mathrm{Mg}, \mathrm{Na}, \mathrm{Rb}$ and $\mathrm{V}$ (illustrated in Figure 3). Other elements, namely Li, $\mathrm{Sb}$ and $\mathrm{Sr}$, were also affected but to a generally lower extent (illustrated in Figure S4). In general, increasing concentrations during flow interruptions may indicate non-equilibrium conditions (maybe both chemical and physical non-equilibrium) most likely caused by presence of a dual-porosity system in which the mass transfer between the mobile and the stagnant zone is controlled by diffusion (slow). As the flow is stopped, diffusion from the stagnant zones can result in increasing concentrations. On the other hand, decreasing solution concentrations during flow interruption may indicate mineral precipitation and/or sorption, i.e. processes which were not occurring during the standard operation of the columns because of nonequilibrium conditions. As indicated earlier, flow interruptions resulted in a slight $\mathrm{pH}$ increase in both columns, though most pronounced for MA during the first flow interruption: an increase of $0.6-0.7 \mathrm{pH}$ units. The change in $\mathrm{pH}$, albeit larger than what was previously observed for MSWI bottom ashes (Hyks et al., 2009a), indicated changes in solution chemistry with extended contact times. Again, this points out to physical non-equilibrium (dual-porosity) and diffusion of $\mathrm{OH}^{-}$from the stagnant zone. FA. The changes in Ca concentrations could be described adequately by changes in equilibrium concentrations of the same minerals proposed for the leaching of continuous $-\mathrm{L}$ columns (at comparable $\mathrm{L} / \mathrm{S}$ ratios), indicating that $\mathrm{Ca}$ mineral equilibrium was maintained during flow interruptions. Likewise, while a marked increase in Ba concentrations was observed in the MA column during the first flow interruption, the changes in the solution concentrations of $\mathrm{Ba}$ 
could be described by equilibrium with barite. $\mathrm{Mg}$ concentrations decreased during flow interruptions, but the predicted minerals in equilibrium with the observed concentrations remained unchanged, i.e. hydrotalcite at $\mathrm{L} / \mathrm{S} 2 \mathrm{~L} / \mathrm{kg}$, while hydrotalcite, brucite, clinoenstatite and forsterite were at L/S $50 \mathrm{~L} / \mathrm{kg}$.

The observed concentrations of $\mathrm{K}, \mathrm{Na}$ and $\mathrm{Rb}$ increased during flow interruptions for both MA and FA ashes, though to different extents - see Figure 3. Analogously to the case of continuous columns, no specific mineral phase could be identified to describe the solution concentrations of these alkali metals, suggesting that $\mathrm{K}$, Na and $\mathrm{Rb}$ were dissolved in the form of halides or (hydr-)oxides. Al concentrations in MA leachates increased considerably during the first flow interruptions, at the same time approaching modelled concentrations for equilibrium with hydrotalcite. Slight variations in the concentration of $\mathrm{Li}, \mathrm{Sb}, \mathrm{Sr}$ and $\mathrm{V}$ were also observed, but only in the case of MA leachates and generally only with respect to one set of flow interruptions (i.e. either at L/S $2 \mathrm{~L} / \mathrm{kg}$ or at L/S $50 \mathrm{~L} / \mathrm{kg}$ ). These changes could not be related to changes in mineral solubility.

Overall, the FA and MA columns responded rather differently to flow interruptions. In general, the FA column showed modest effects from flow interruptions, whereas clear effects were observed for the MA column. While inconclusive, based on these results as well as literature data this difference in behaviour may be caused by differences in particle size distributions, particle shapes and porosity, which may then affect mineral dissolution and overall equilibrium conditions between the two materials.

\subsection{Wood ash potential and management}

\subsubsection{Primary nutrients}

Upon applying wood combustion ash on soil, the potential release of nutrients may improve the fertility of the soil, especially if primary plant macronutrients $(\mathrm{P}, \mathrm{K}$ and $\mathrm{N})$ are released or become accessible for plant uptake. Phosphorous (P) is relatively abundant in wood ash $\left(\sim 10^{4} \mathrm{mg} / \mathrm{kg}\right.$ in our samples $)$, but only a very small and typically barely detectable fraction has been reported to be water-soluble (see Section 3.1.1). On the other hand, based on ammonium citrate and citric acid extractions (common solvents used to test phosphatic fertilisers), wood ash appears to release about 57-78 \% of the total P content (Brod et al., 2015; Erich, 1991; Yusiharni et al., 2007). As such, these extraction tests are somewhat in contrast to batch leaching experiments reported in the literature, as well as to our column experiments, in which significantly lower releases were found. This may indicate that during conditions where the leaching system is controlled by the ashes, $\mathrm{P}$ release can be expected to be low. On the other hand, if the more acidic 
conditions of forest soils control the leaching system, the acidic conditions of typical availability tests may be more relevant.

Potassium (K) is abundant in wood ash $\left(\sim 10^{4} \mathrm{mg} / \mathrm{kg}\right.$ in our samples), but in contrast to $\mathrm{P}$ it is rather soluble and readily available (see Section 3.1.1). Based on our column results, relatively large amounts of $\mathrm{K}$ can be expected to be released shortly after ash application. On the contrary, relatively low nitrogen $(\mathrm{N})$ contents are observed in wood ashes compared to the input biomass fuel because of the low volatilisation temperature of N (e.g. Ingerslev et al., 2011; Misra et al., 1993). Based on the potential release of N, P and K, the fertilising value of wood ashes may be limited, but still potentially valuable in the case of acidic/neutral soils with $\mathrm{P}$ and/or $\mathrm{K}$ deficiencies, as it appears to be the case for many

\subsubsection{Typical elements of environmental concern}

Standard batch, column and $\mathrm{pH}$-dependent leaching tests are useful for both basic leaching characterisation and testing compliance with regulatory limits. Table 3 compares results from the column experiments (at cumulative L/S $10 \mathrm{~L} / \mathrm{kg}$ ) with the waste acceptance criteria (WAC) for landfilling (Directive 2003/33/EC). Both MA and FA complied with WAC for landfills receiving non-hazardous waste, but they exceeded WAC for landfills receiving inert waste for Ba, chloride and sulphate in the case of MA, and chloride, $\mathrm{Cr}$, Mo and sulphate in the case of FA. This should not be ignored, since wood ashes are considered useful for application on land in many countries. Moreover, in Denmark, wood ash utilisation is currently not subjected to any specific leaching requirements, as the only limits defined by Danish authorities are set for the total composition and electrical conductivity (which in turn define the maximum

\subsubsection{Liming}

Both ash samples generated strongly alkaline leachates across the investigated $\mathrm{L} / \mathrm{S}$ range, e.g. above $\mathrm{pH} 10.9$ at $\mathrm{L} / \mathrm{S}$ $1000 \mathrm{~L} / \mathrm{kg}$. The release of "total alkalinity" at L/S $1000 \mathrm{~L} / \mathrm{kg}$ was calculated to be $3.8 \mathrm{meq} / \mathrm{g}$ for MA (equivalent to the ANC of $0.19 \mathrm{~g}$ of $\mathrm{CaCO}_{3}$ ) and $7.6 \mathrm{meq} / \mathrm{g}$ for $\mathrm{FA}$ (equivalent to the $\mathrm{ANC}$ of $0.38 \mathrm{~g}$ of $\mathrm{CaCO}_{3}$ ) - which further increased up to $9.0 \mathrm{meq} / \mathrm{g}$ for $\mathrm{FA}$ at $\mathrm{L} / \mathrm{S} 2300 \mathrm{~L} / \mathrm{kg}$ (i.e. $\sim 0.45 \mathrm{~g}$ of $\mathrm{CaCO}_{3}$ ). Although a wide range of results for calcium carbonate equivalents of wood ashes has been reported in the literature, these levels have been typically observed between one-third and two-thirds of pure limestone (Cabral et al., 2008; Erich, 1991; Vance, 1996). This is in overall 
accordance with our releases of "total alkalinity". As such, the herein investigated wood ashes may represent a considerable liming potential for acidic soils.

Two types of alkalinity were calculated, namely "standard alkalinity" and "total alkalinity". Until L/S $300 \mathrm{~L} / \mathrm{kg}$ for MA and $600 \mathrm{~L} / \mathrm{kg}$ for FA these two values were comparable, but at higher L/S ratios "total alkalinity" was typically about $20 \%$ higher. This indicates not only that different alkaline species are released at higher L/S ratios, but also the potential long-term importance of silicates after washout of carbonates, bicarbonates and hydroxides. Accordingly, it was observed that "standard alkalinity" released at L/S $1000 \mathrm{~L} / \mathrm{kg}$ corresponded to about $85 \%$ of the $\mathrm{ANC}_{4.5}$ of MA and $64 \%$ of the $\mathrm{ANC}_{4.5}$ of FA. This indicates that a large part of the actual buffer capacity of the ashes was depleted during the - very long - column experiments, thereby supporting a potential change in the dissolved alkaline species.

\section{CONCLUSIONS}

Column leaching experiments involving two types of wood combustion ashes (fly ash and mixed ash) were completed, covering L/S ratios up to $2300 \mathrm{~L} / \mathrm{kg}$. Despite potential non-equilibrium conditions, long-term leaching could be described adequately as a function of the L/S ratio, by combining results from several columns of various lengths together. The observed concentrations of $\mathrm{Ca}, \mathrm{Mg}, \mathrm{Al}, \mathrm{Ba}$, sulphate and $\mathrm{Si}$ from both ash materials could be described by the dissolution of a limited selection of minerals, several of these relevant for more than a single element at the same time. Depletion of more soluble mineral phases was likely to occur during our long-term leaching experiment, in turn promoting favourable conditions for the dissolution of new minerals, stable at well-defined L/S intervals - as indicated by the speciation calculations. In the case of trace elements, mineral dissolution alone was not sufficient to describe the observed concentrations, indicating that other processes, such as surface complexation and formation of solid solutions were likely to occur, too. At L/S $1000 \mathrm{~L} / \mathrm{kg}$, the cumulative releases of K, S, Na, Ca and Rb were observed at 40-100 \%, followed by Ba, Sb, Sr and V at 15-40\%, and with $\mathrm{Al}, \mathrm{Mg}, \mathrm{Zn}, \mathrm{Cd}, \mathrm{Co}, \mathrm{Fe}, \mathrm{Pb}, \mathrm{Tl}, \mathrm{Mn}$ and $\mathrm{P}$ at levels below $5 \%$. As shown by the relatively large differences in the calculated cumulative releases, leaching data corresponding to L/S 10 $\mathrm{L} / \mathrm{kg}$ are generally not sufficient for estimating leaching at considerably higher L/S ratios, e.g. $1000 \mathrm{~L} / \mathrm{kg}$. The observed released alkalinity at the cumulative L/S $1000 \mathrm{~L} / \mathrm{kg}$ corresponded to about 20-40\% of calcium carbonate equivalents, indicating the relatively high liming value of the investigated wood ash samples.

\section{ACKNOWLEDGEMENTS}


The anonymous reviewers are gratefully acknowledged for the constructive comments provided. The research group is acknowledged for the help received during the collection of leachates. The study was supported by The Danish Council for Strategic Research (grant no 0603-00587B) and the Technical University of Denmark, and it is part of the ASHBACK project (http://www.ashback.dk/).

\section{REFERENCES}

Allegrini, E., Boldrin, A., Polettini, A., Pomi, R., Astrup, T., 2011. Leaching from biomass gasification residues, in: Proceedings Sardinia 2011, Thirteenth International Waste Management and Landfill Symposium S. Margherita Di Pula, Cagliari, Italy; 3 - 7 October 2011. pp. 3-7.

ASTM C702/C702M, 2011. Standard Practice for Reducing Samples of Aggregate to Testing Size. West Conshohocken, PA. doi:http://dx.doi.org/10.1520/C0702_C0702M-11

Astrup, T., Dijkstra, J.J., Comans, R.N.J., van der Sloot, H., Christensen, T.H., 2006. Geochemical modeling of leaching from MSWI air-pollution-control residues. Environ. Sci. Technol. 40, 3551-7. doi:10.1021/es052250r

Brod, E., Øgaard, A.F., Haraldsen, T.K., Krogstad, T., 2015. Waste products as alternative phosphorus fertilisers part II: predicting $\mathrm{P}$ fertilisation effects by chemical extraction. Nutr. Cycl. Agroecosystems 103, 187-199. doi:10.1007/s10705-015-9731-4

Butera, S., Hyks, J., Christensen, T.H., Astrup, T.F., 2015. Construction and demolition waste: Comparison of standard up-flow column and down-flow lysimeter leaching tests. Waste Manag. 43, 386-397. doi:10.1016/j.wasman.2015.04.032

Cabral, F., Ribeiro, H.M., Hilário, L., Machado, L., Vasconcelos, E., 2008. Use of pulp mill inorganic wastes as alternative liming materials. Bioresour. Technol. 99, 8294-8298. doi:10.1016/j.biortech.2008.03.001

Chirenje, T., Rivero, C., Ma, L.Q., Chirenje, T., Rivero, C., 2002. Leaching of As and Cr in Wood-Ash-Amended Soil Columns. Soil Sediment Contam. 11, 359-375. doi:10.1080/20025891106790

Cornelis, G., Johnson, C.A., Gerven, T. Van, Vandecasteele, C., 2008. Leaching mechanisms of oxyanionic metalloid and metal species in alkaline solid wastes: A review. Appl. Geochemistry 23, 955-976. doi:10.1016/j.apgeochem.2008.02.001

Dahl, O., Nurmesniemi, H., Pöykiö, R., Watkins, G., 2010. Heavy metal concentrations in bottom ash and fly ash fractions from a large-sized (246 MW) fluidized bed boiler with respect to their Finnish forest fertilizer limit values. Fuel Process. Technol. 91, 1634-1639. doi:10.1016/j.fuproc.2010.06.012 
Danish Energy Agency, 2017. Energy statistics 2015: data, tables, statistics and maps. Copenhagen, Denmark.

481 Demeyer, A., Voundi Nkana, J.C., Verloo, M.G., 2001. Characteristics of wood ash and influence on soil properties and nutrient uptake: an overview. Bioresour. Technol. 77, 287-295.

DEPA, 2008. BEK 818 : 2008. Statutory Order on the use of bio-ash for agricultural purposes (Bekendtgørelse om anvendelse af bioaske til jordbrugsformål - Bioaskebekendtgørelsen). [in Danish]. Danish Environmental Protection Agency. Copenhagen, Denmark.

Dijkstra, J.J., van der Sloot, H., Comans, R.N.J., 2006. The leaching of major and trace elements from MSWI bottom

Dijkstra, J.J., van der Sloot, H., Comans, R.N.J., 2002. Process identification and model development of contaminant transport in MSWI bottom ash. Waste Manag. 22, 531-541.

Directive 2003/33/EC, 2003. Council Decision of 19 December 2002 establishing criteria and procedures for the acceptance of waste at landfills pursuant to article 16 of and Annex II to Directive 1999/31/EC.

Drift, A. Van Der, Doorn, J. Van, Vermeulen, J.W., 2001. Ten residual biomass fuels for circulating fluidized-bed gasification. Biomass and Bioenergy 20, 45-56. doi:10.1016/S0961-9534(00)00045-3

EN 14405:, 2017. Dansk standard Karakterisering af affald - Test af udvaskningsegenskaber - Opstrøms perkolationstest (under fastlagte betingelser). Characterization of waste - Leaching behaviour test - Up-flow percolation test (under specified conditions).

Erich, M.S., 1991. Agronomic Effectiveness of Wood Ash as a Source of Phosphorus and Potassium. J. Environ. Qual. 20, 576-581. doi:10.2134/jeq1991.00472425002000030012x

Eriksson, J., 1996. Dissolution of hardened wood ash in forest soils: studies in a column experiment (Härdade vedaskors upplösning i skogsjord Ramprogram askåterföring). [in Swedish]. Stockholm, Sweden.

Freire, M., Lopes, H., Tarelho, L.A.C., 2015. Critical aspects of biomass ashes utilization in soils: Composition, leachability, PAH and PCDD/F. Waste Manag. 46, 304-315. doi:10.1016/j.wasman.2015.08.036

Gori, M., Bergfeldt, B., Pfrang-Stotz, G., Reichelt, J., Sirini, P., 2011. Effect of short-term natural weathering on MSWI and wood waste bottom ash leaching behaviour. J. Hazard. Mater. 189, 435-43. doi:10.1016/j.jhazmat.2011.02.045

Holmberg, S.L., Claesson, T., 2001. Mineralogy of granulated wood ash from a heating plant in Kalmar, Sweden. Environ. Geol. 40, 820-828. doi:10.1007/s002540100261

Holmberg, S.L., Lind, B.B., Claesson, T., 2000. Chemical composition and leaching characteristics of granules made of 
wood ash and dolomite. Environ. Geol. 40, 1-10. doi:10.1007/PL00013327

Huang, H., Campbell, A.G., Folk, R., Mahler, R.L., 1992. Wood ash as a soil additive and liming agent for wheat: Field studies. Commun. Soil Sci. Plant Anal. 23, 25-33. doi:10.1080/00103629209368567

Hyks, J., Astrup, T., Christensen, T.H., 2009a. Leaching from MSWI bottom ash: evaluation of non-equilibrium in column percolation experiments. Waste Manag. 29, 522-9. doi:10.1016/j.wasman.2008.06.011

Hyks, J., Astrup, T., Christensen, T.H., 2009b. Long-term leaching from MSWI air-pollution-control residues: Leaching characterization and modeling. J. Hazard. Mater. 162, 80-91. doi:10.1016/j.jhazmat.2008.05.011

Hyks, J., Nesterov, I., Mogensen, E., Jensen, P. a., Astrup, T., 2011. Leaching from waste incineration bottom ashes treated in a rotary kiln. Waste Manag. Res. 29, 995-1007. doi:10.1177/0734242X11417490

Ingerslev, M., Mälkönen, E., Nilsen, P., Nohrstedt, H.-örjan, Óskarsson, H., Raulund-Rasmussen, K., 2001. Main Findings and Future Challenges in Forest Nutritional Research and Management in the Nordic Countries. Scand.

Komonweeraket, K., Cetin, B., Aydilek, A.H., Benson, C.H., Edil, T.B., 2015. Effects of pH on the leaching mechanisms of elements from fly ash mixed soils. Fuel 140, 788-802. doi:10.1016/j.fuel.2014.09.068 J. For. Res. 16, 488-501. doi:10.1080/02827580152699330

Ingerslev, M., Skov, S., Sevel, L., Pedersen, L.B., 2011. Element budgets of forest biomass combustion and ash fertilisation - A Danish case-study. Biomass and Bioenergy 35, 2697-2704. doi:10.1016/j.biombioe.2011.03.018

Kinniburgh, D.G., Milne, C.J., Benedetti, M.F., Pinheiro, J.P., Filius, J., Koopal, L.K., Van Riemsdijk, W.H., 1996. Metal Ion Binding by Humic Acid: Application of the NICA-Donnan Model. Environ. Sci. Technol. 30, 16871698. doi:10.1021/es950695h

Ludwig, B., Khanna, P., Prenzel, J., Beese, F., 2005. Heavy metal release from different ashes during serial batch tests using water and acid. Waste Manag. 25, 1055-1066. doi:10.1016/j.wasman.2005.01.007

Magdziarz, A., Dalai, A.K., Koziński, J.A., 2016. Chemical composition, character and reactivity of renewable fuel ashes. Fuel 176, 135-145. doi:10.1016/j.fuel.2016.02.069

Maresca, A., Hyks, J., Astrup, T.F., 2017. Recirculation of biomass ashes onto forest soils: ash composition, mineralogy and leaching properties (in press). Waste Manag. doi:https://doi.org/10.1016/j.wasman.2017.09.008 
Meeussen, J.C.L., 2003. ORCHESTRA: An Object-Oriented Framework for Implementing Chemical Equilibrium Models. Environ. Sci. Technol. 37, 1175-1182. doi:10.1021/es025597s

Meima, J.A., Comans, R.N.J., 1999. The leaching of trace elements from municipal solid waste incinerator bottom ash at different stages of weathering. Appl. Geochemistry 14, 159-171.

Meima, J.A., Comans, R.N.J., 1997. Overview of geochemical processes controlling leaching characteristics of MSWI bottom ash. Stud. Environ. Sci. 71, 447-457. doi:10.1016/S0166-1116(97)80228-2

Meiwes, K.J., 1995. Application of lime and wood ash to decrease acidification of forest soils. Water, Air, Soil Pollut. 85, 143-152. doi:10.1007/BF00483696

Mellbo, P., Sarenbo, S., Stålnacke, O., Claesson, T., 2008. Leaching of wood ash products aimed for spreading in forest floors - Influence of method and L/S ratio. Waste Manag. 28, 2235-44. doi:10.1016/j.wasman.2007.09.037

Milne, C.J., Kinniburgh, D.G., van Riemsdijk, W.H., Tipping, E., 2003. Generic NICA-Donnan model parameters for

Misra, M.K., Ragland, K.W., Baker, A.J., 1993. Wood ash composition as a function of furnace temperature. Biomass and Bioenergy 4, 103-116. doi:10.1016/0961-9534(93)90032-Y

Pitman, R.M., 2006. Wood ash use in forestry - a review of the environmental impacts. Forestry 79, $563-588$. doi:10.1093/forestry/cpl041

Polettini, A., Pomi, R., 2004. The leaching behavior of incinerator bottom ash as affected by accelerated ageing. J. Hazard. Mater. 113, 209-15. doi:10.1016/j.jhazmat.2004.06.009

Pöykiö, R., Rönkkömaki, H., Nurmesniemi, H., Peramaki, P., Popov, K., Valimaki, I., Tuomi, T., 2009. Chemical and physical properties of cyclone fly ash from the grate-fired boiler incinerating forest residues at a small municipal district heating plant (6MW). J. Hazard. Mater. 162, 1059-64. doi:10.1016/j.jhazmat.2008.05.140

Reimann, C., Ottesen, R.T., Andersson, M., Arnoldusser, A., Koller, F., Enqlmaier, P., 2008. Element levels in birch and spruce wood ashes - green energy? Sci. Total Environ. 393, 191-197. doi:10.1016/j.scitotenv.2008.01.015

Sabbas, T., Polettini, A., Pomi, R., Astrup, T., Hjelmar, O., Mostbauer, P., Cappai, G., Magel, G., Salhofer, S., Speiser, C., Heuss-Assbichler, S., Klein, R., Lechner, P., 2003. Management of municipal solid waste incineration residues. Waste Manag. 23, 61-88. doi:10.1016/S0956-053X(02)00161-7

Sano, T., Miura, S., Furusawa, H., Kaneko, S., Yoshida, T., Nomura, T., Ohara, S., 2013. Composition of inorganic elements and the leaching behavior of biomass combustion ashes discharged from wood pellet boilers in Japan. J. Wood Sci. 59, 307-320. doi:10.1007/s10086-013-1337-3 
Skov, S., Ingerslev, M., 2013. Wood ash in practice (Flisaske i praksis). [in Danish]. Institut for Geovidenskab og Naturforvaltning - Københavns Universitet. Frederiksberg, Denmark.

Steenari, B.-M., Lindqvist, O., 1997. Stabilisation of biofuel ashes for recycling to forest soil. Biomass and Bioenergy $13,39-50$.

Steenari, B.M., Karlfeldt Fedje, K., 2010. Addition of kaolin as potassium sorbent in the combustion of wood fuel Effects on fly ash properties. Fuel 89, 2026-2032. doi:10.1016/j.fuel.2010.02.006

Steenari, B.M., Karlsson, L.G., Lindqvist, O., 1999a. Evaluation of the leaching characteristics of wood ash and the influence of ash agglomeration. Biomass and Bioenergy 16, 119-136. doi:10.1016/S0961-9534(98)00070-1

Steenari, B.M., Schelander, S., Lindqvist, O., 1999b. Chemical and leaching characteristics of ash from combustion of coal, peat and wood in a 12 MW CFB - a comparative study. Fuel 78, 249-258. doi:10.1016/S00162361(98)00137-9

Supancic, K., Obernberger, I., Kienzl, N., Arich, A., 2014. Conversion and leaching characteristics of biomass ashes during outdoor storage - Results of laboratory tests. Biomass and Bioenergy 61, 211-226. doi:10.1016/j.biombioe.2013.12.014

The Danish Council on Climate Change, 2015. Converting with care: Status and challenges for Danish climate policy.

van der Sloot, H., van Zomeren, A., 2010. Geochemical speciation modelling of $\mathrm{pH}$ dependence test data as alternative to sequential chemical extraction, in: Proceedings Venice 2010, Third International Symposium on Energy from Biomass and Waste.

Vance, E.D., 1996. Land application of wood-fired and combination boiler ashes: An overview. J. Environ. Qual. 25, 937. doi:10.2134/jeq1996.00472425002500050002x

Vassilev, S. V., Baxter, D., Andersen, L.K., Vassileva, C.G., 2013a. An overview of the composition and application of biomass ash. Part 1. Phase-mineral and chemical composition and classification. Fuel 105, 40-76. doi:10.1016/j.fuel.2012.09.041

Vassilev, S. V., Baxter, D., Vassileva, C.G., 2013b. An overview of the behaviour of biomass during combustion: Part I. Phase-mineral transformations of organic and inorganic matter. Fuel 112, 391-449. doi:10.1016/j.fuel.2013.05.043

Werkelin, J., Lindberg, D., Bostrom, D., Skrifvars, B.J., Hupa, M., 2011. Ash-forming elements in four Scandinavian wood species part 3: Combustion of five spruce samples. Biomass and Bioenergy 35, $725-733$. doi:10.1016/j.biombioe.2010.10.010 
596 Yusiharni, B.E., Ziadi, H., Gilkes, R.J., 2007. A laboratory and glasshouse evaluation of chicken litter ash, wood ash, 597 and iron smelting slag as liming agents and P fertilisers. Aust. J. Soil Res. 45, 374-389. doi:10.1071/SR06136 598 599 
600 Table 1. Chemical characterisation of the wood ash samples, i.e. MA and FA. The values are expressed in mg/kg dry 601 weight, unless otherwise specified. All analyses were carried out in at least duplicates. Values in brackets represent the 602 relative standard deviation. [TOC: total organic carbon; MC: moisture content]. Adapted from Maresca et al. (2017).

\begin{tabular}{ccc}
\hline & MA & FA \\
\hline MC (\%) & 0.151 & 47.3 \\
TOC & $58400(2.5 \%)$ & $73900(29 \%)$ \\
Al & $12400(4.7 \%)$ & $10800(14 \%)$ \\
As & $1.82(3.8 \%)$ & $2.68(8.8 \%)$ \\
Ba & $1170(9.9 \%)$ & $1550(0.056 \%)$ \\
$\mathbf{B e}$ & $1.91(58 \%)$ & $0.798(1.6 \%)$ \\
$\mathbf{C a}$ & $135000(2.8 \%)$ & $263000(3.1 \%)$ \\
$\mathbf{C d}$ & $3.99(3.4 \%)$ & $16.3(0.74 \%)$ \\
$\mathbf{C o}$ & $5.49(0.21 \%)$ & $5.79(2.0 \%)$ \\
$\mathbf{C r}$ & $26.6(3.1 \%)$ & $60.6(3.4 \%)$ \\
$\mathbf{C u}$ & $60.4(2.9 \%)$ & $115(1.0 \%)$ \\
$\mathbf{F e}$ & $6720(1.9 \%)$ & $6090(2.4 \%)$ \\
$\mathbf{K}$ & $39400(3.8 \%)$ & $51200(4.7 \%)$ \\
$\mathbf{L i}$ & $5.70(27 \%)$ & $6.73(0.17 \%)$ \\
$\mathbf{M g}$ & $12700(2.3 \%)$ & $30000(3.1 \%)$ \\
$\mathbf{M n}$ & $7430(2.7 \%)$ & $11000(1.6 \%)$ \\
$\mathbf{M o}$ & $1.81(4.5 \%)$ & $3.61(14 \%)$ \\
$\mathbf{N a}$ & $10500(8.0 \%)$ & $12000(25 \%)$ \\
$\mathbf{N}$ & $700(2.9 \%)$ & $1670(3.5 \%)$ \\
$\mathbf{N i}$ & $16.1(2.0 \%)$ & $22.4(0.76 \%)$ \\
$\mathbf{P}$ & $10000(2.6 \%)$ & $21400(1.8 \%)$ \\
$\mathbf{P b}$ & $13.8(4.6 \%)$ & $55.3(2.0 \%)$ \\
$\mathbf{S}$ & $2450(5.3 \%)$ & $8490(2.8 \%)$ \\
$\mathbf{S b}$ & $1.33(3.0 \%)$ & $2.44(1.6 \%)$ \\
$\mathbf{S e}$ & $<16.7$ & $<16.7$ \\
$\mathbf{S i}$ & $254000(6.3 \%)$ & $124000(33 \%)$ \\
$\mathbf{S n}$ & $1.07(3.6 \%)$ & $2.51(3.3 \%)$ \\
$\mathbf{S r}$ & $708(3.1 \%)$ & $1240(3.6 \%)$ \\
$\mathbf{T I}$ & $0.217(0.93 \%)$ & $1.98(2.8 \%)$ \\
$\mathbf{V}$ & $15.9(4.0 \%)$ & $9.18(1.3 \%)$ \\
$\mathbf{Z n}$ & $340(3.2 \%)$ & $924(0.78 \%)$ \\
\hline & &
\end{tabular}

603

604 
605 Table 2. Main characteristics of the MA and FA columns. [-L: long column; -M: medium column; -S: short column;

606 _FI: flow interrupted column; *: not available; ww: wet weight].

\begin{tabular}{lccccccccc}
\hline & & MA-L & MA-L_FI & MA-M & MA-S & FA-L & FA-L_FI & FA-M & FA-S \\
\hline Column diameter & $\mathrm{cm}$ & 5.0 & 5.0 & 5.0 & 5.0 & 5.0 & 5.0 & 5.0 & 5.0 \\
Column height & $\mathrm{cm}$ & 30 & 30 & 13 & 4.5 & 30 & 30 & 13 & 4.5 \\
Ash filling volume & $\mathrm{cm}^{3}$ & 540 & 540 & 220 & 56 & 540 & 540 & 220 & 49 \\
Ash amount & $\mathrm{gww}_{w w}$ & 530 & 530 & 210 & 43 & 540 & 510 & 210 & 34 \\
Test duration & days & 150 & 157 & 150 & 150 & 150 & 150 & 150 & 150 \\
Final L/S ratio & $\mathrm{L} / \mathrm{kg}$ & 75 & 54 & 206 & 1020 & 146 & 101 & 388 & 2330 \\
Estimated pore volume & $\mathrm{cm}^{3}$ & $*$ & 330 & $*$ & $*$ & $*$ & 160 & $*$ & $*$ \\
\hline
\end{tabular}

607 
608 Table 3. Calculated cumulative releases from column tests, expressed per dry weight of material. Releases at L/S 10

$609 \mathrm{~L} / \mathrm{kg}$ are calculated based on -L columns data; releases at L/S $1000 \mathrm{~L} / \mathrm{kg}$ are calculated based on -S columns data.

610 Waste acceptance criteria (WAC) for landfills receiving inert and non-hazardous waste are reported for comparison

611 (Directive 2003/33/EC). [**: the calculated release was $>100 \%$; <: the area underneath LOQ exceeded more than $30 \%$

612 the overall area calculated for that specific element; $\approx$ : the area underneath LOQ was in the range $10 \%-30 \%$ of the

613 overall area calculated for that specific element]

\begin{tabular}{|c|c|c|c|c|c|}
\hline & $\begin{array}{c}\text { Released } \\
\text { fraction }\end{array}$ & $\begin{array}{c}M A \\
10 \mathrm{~L} / \mathrm{kg} \\
\end{array}$ & $\begin{array}{c}\text { FA } \\
10 \mathrm{~L} / \mathrm{kg} \\
\end{array}$ & $\begin{array}{c}M A \\
1000 \mathrm{~L} / \mathrm{kg} \\
\end{array}$ & $\begin{array}{c}F A \\
1000 \mathrm{~L} / \mathrm{kg} \\
\end{array}$ \\
\hline Al & $\%$ & 0.0031 & 0.0032 & 1.6 & 0.64 \\
\hline As & $\%$ & 0.24 & $<0.11$ & $<14$ & $<9.8$ \\
\hline $\mathrm{Ba}$ & $\%$ & 4.5 & 0.21 & 18 & 18 \\
\hline $\mathrm{Ca}$ & $\%$ & 6.5 & 2.6 & 40 & 43 \\
\hline Cd & $\%$ & $<0.049$ & $<0.012$ & $<4.9$ & $<1.2$ \\
\hline $\mathrm{Cr}$ & $\%$ & $<0.025$ & 11 & 4.1 & 18 \\
\hline $\mathrm{Cu}$ & $\%$ & $<0.011$ & 0.18 & $<12$ & $<6.2$ \\
\hline $\mathrm{Fe}$ & $\%$ & $<0.0003$ & 0.0006 & $<0.019$ & $<0.030$ \\
\hline $\mathrm{K}$ & $\%$ & 39 & 89 & 64 & 88 \\
\hline Mg & $\%$ & 0.0010 & 0.0004 & 1.1 & 0.30 \\
\hline Mn & $\%$ & $<0.0001$ & $<0.0001$ & $<0.0099$ & $<0.0067$ \\
\hline Mo & $\%$ & $\approx 16$ & 34 & $<100^{* *}$ & $<100^{* *}$ \\
\hline $\mathrm{N}-\mathrm{NO}_{3}{ }^{-}$ & $\%$ & 0.43 & 3.5 & $<2.6$ & 8.9 \\
\hline $\mathrm{Na}$ & $\%$ & 16 & 41 & 40 & 53 \\
\hline $\mathrm{Ni}$ & $\%$ & $<0.27$ & $\approx 0.23$ & $<27$ & $<26$ \\
\hline $\mathbf{P}$ & $\%$ & $<0.0020$ & $\approx 0.0015$ & $<0.20$ & $<0.095$ \\
\hline $\mathrm{Pb}$ & $\%$ & 0.24 & 0.17 & $\approx 0.41$ & 0.81 \\
\hline S & $\%$ & 64 & 79 & $100^{* *}$ & $100^{* *}$ \\
\hline Sb & $\%$ & $<0.064$ & $<0.033$ & 19 & 16 \\
\hline Si & $\%$ & 0.0017 & 0.0050 & 4.8 & 11 \\
\hline $\mathrm{Sr}$ & $\%$ & 12 & 10 & 41 & 27 \\
\hline V & $\%$ & $<0.040$ & $\approx 0.079$ & 29 & 21 \\
\hline \multirow[t]{2}{*}{$\mathrm{Zn}$} & $\%$ & 0.41 & 0.050 & 1.4 & 1.1 \\
\hline & $\begin{array}{l}\text { Released } \\
\text { fraction }\end{array}$ & $\begin{array}{c}\text { MA } \\
10 \mathrm{~L} / \mathrm{kg}\end{array}$ & $\begin{array}{c}\text { FA } \\
10 \mathrm{~L} / \mathrm{kg}\end{array}$ & $\begin{array}{c}\text { WAC } \\
\text { inert } \\
10 \mathrm{~L} / \mathrm{kg}\end{array}$ & $\begin{array}{c}\text { WAC } \\
\text { non-haz. } \\
10 \mathrm{~L} / \mathrm{kg}\end{array}$ \\
\hline As & $\mathrm{mg} / \mathrm{kg}$ & 0.0043 & $<0.0029$ & 0.5 & 2 \\
\hline $\mathrm{Ba}$ & $\mathrm{mg} / \mathrm{kg}$ & 52 & 3.2 & 20 & 100 \\
\hline Cd & $\mathrm{mg} / \mathrm{kg}$ & $<0.0020$ & $<0.0019$ & 0.04 & 1 \\
\hline $\mathrm{Cl}$ & $\mathrm{mg} / \mathrm{kg}$ & 960 & 4200 & 800 & 15000 \\
\hline $\mathrm{Cr}$ & $\mathrm{mg} / \mathrm{kg}$ & $<0.0066$ & 6.9 & 0.5 & 10 \\
\hline $\mathrm{Cu}$ & $\mathrm{mg} / \mathrm{kg}$ & $<0.0066$ & 0.21 & 2 & 50 \\
\hline Mo & $\mathrm{mg} / \mathrm{kg}$ & $\approx 0.29$ & 1.2 & 0.5 & 10 \\
\hline $\mathrm{Ni}$ & $\mathrm{mg} / \mathrm{kg}$ & $<0.044$ & $\approx 0.051$ & 0.4 & 10 \\
\hline $\mathrm{Pb}$ & $\mathrm{mg} / \mathrm{kg}$ & 0.034 & 0.091 & 0.5 & 10 \\
\hline $\mathrm{Sb}$ & $\mathrm{mg} / \mathrm{kg}$ & $<0.0008$ & $<0.0008$ & 0.06 & 0.7 \\
\hline $\mathrm{Zn}$ & $\mathrm{mg} / \mathrm{kg}$ & 1.4 & 0.47 & 4 & 50 \\
\hline $\mathrm{SO}_{4}{ }^{2-}$ & $\mathrm{mg} / \mathrm{kg}$ & 1500 & 5200 & 1000 & 20000 \\
\hline DOC & $\mathrm{mg} / \mathrm{kg}$ & 18 & 130 & 500 & 800 \\
\hline
\end{tabular}

614 

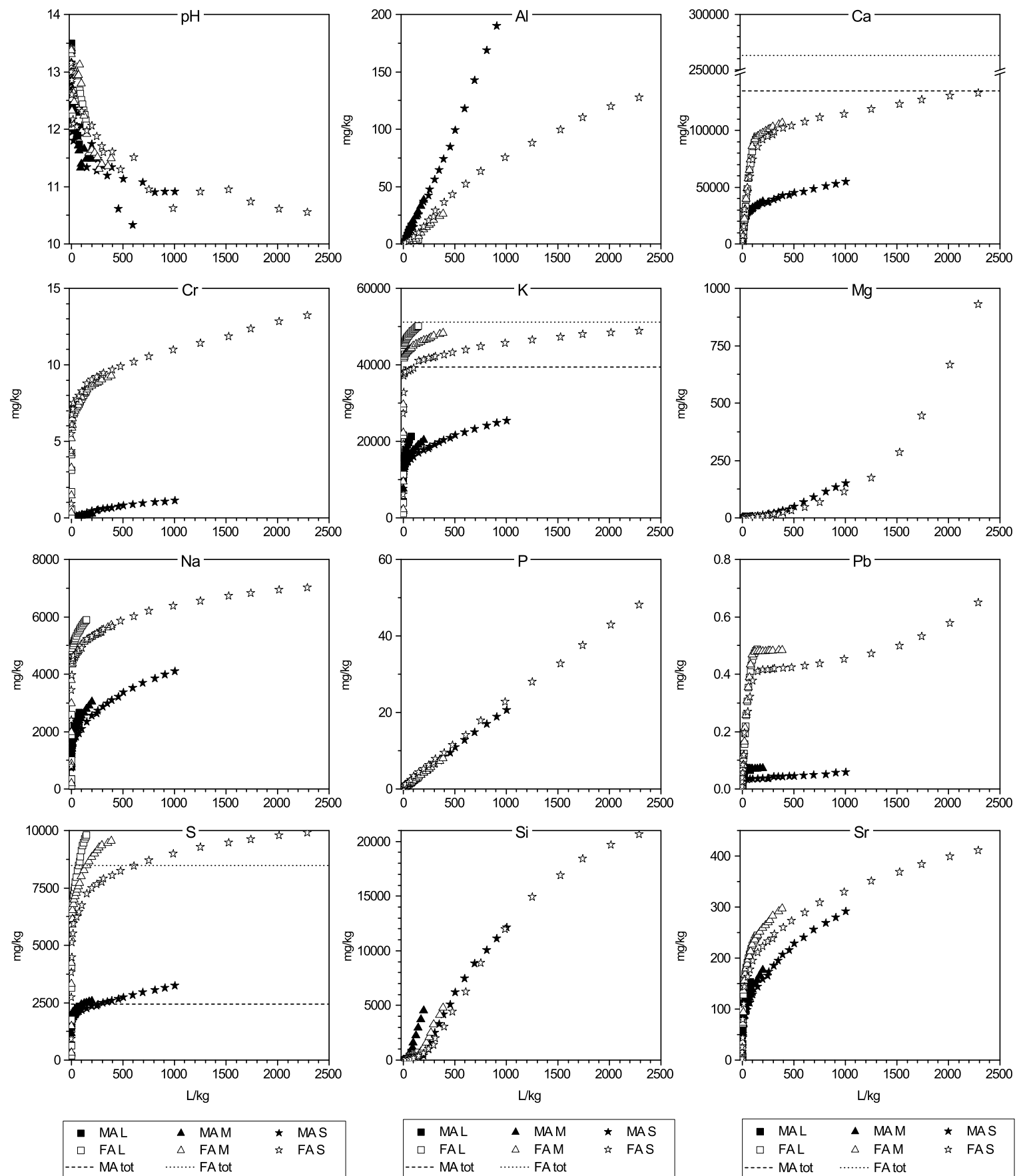

\begin{tabular}{|c|c|c|}
\hline - MAL & $\Delta \quad M A M$ & * MAS \\
\hline$\square \quad F A L$ & $\triangle$ FAM & $\Leftrightarrow$ FAS \\
\hline
\end{tabular}

Figure 1. Cumulative releases of $\mathrm{Al}, \mathrm{Ca}, \mathrm{Cr}, \mathrm{K}, \mathrm{Mg}, \mathrm{Na}, \mathrm{P}, \mathrm{Pb}, \mathrm{S}, \mathrm{Si}, \mathrm{Sr}$, and $\mathrm{pH}$ from continuous $\mathrm{MA}$ and $\mathrm{FA}$ columns.

618 Results are expressed in $\mathrm{mg} / \mathrm{kg}$, except for $\mathrm{pH}$. Total contents in the ash samples are shown only for the elements which 619 cumulative release approached the total content levels. Note the break of the y-axis for Ca. [-L: long column; -M:

620 medium column; -S: short column]. 

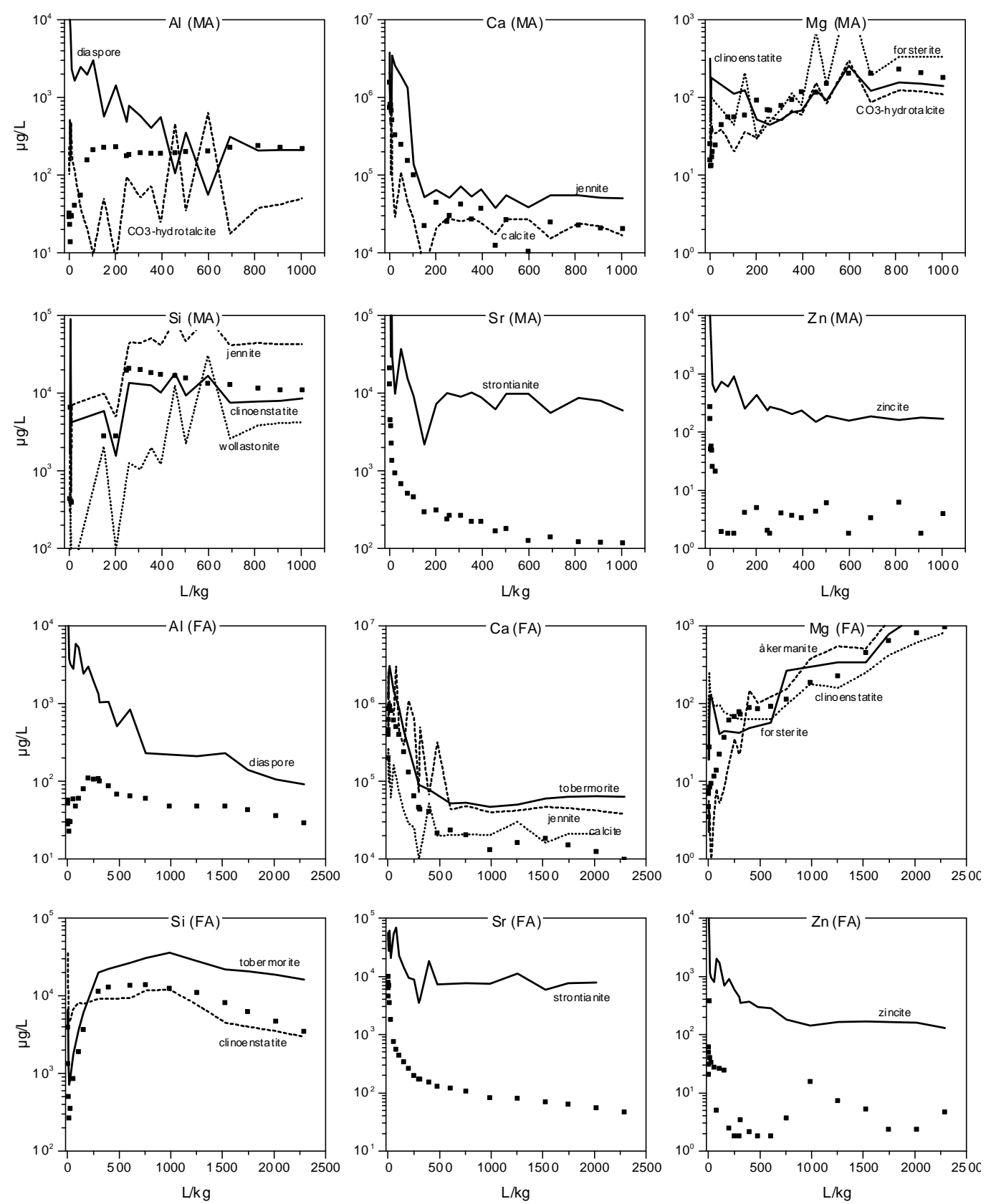

Figure 2. Speciation model results in comparison with the observed concentrations for $\mathrm{Al}, \mathrm{Ca}, \mathrm{Mg}, \mathrm{Si}, \mathrm{Sr}$ and $\mathrm{Zn}$ in the leachates from -S columns, for MA (above) and FA (below) samples. 

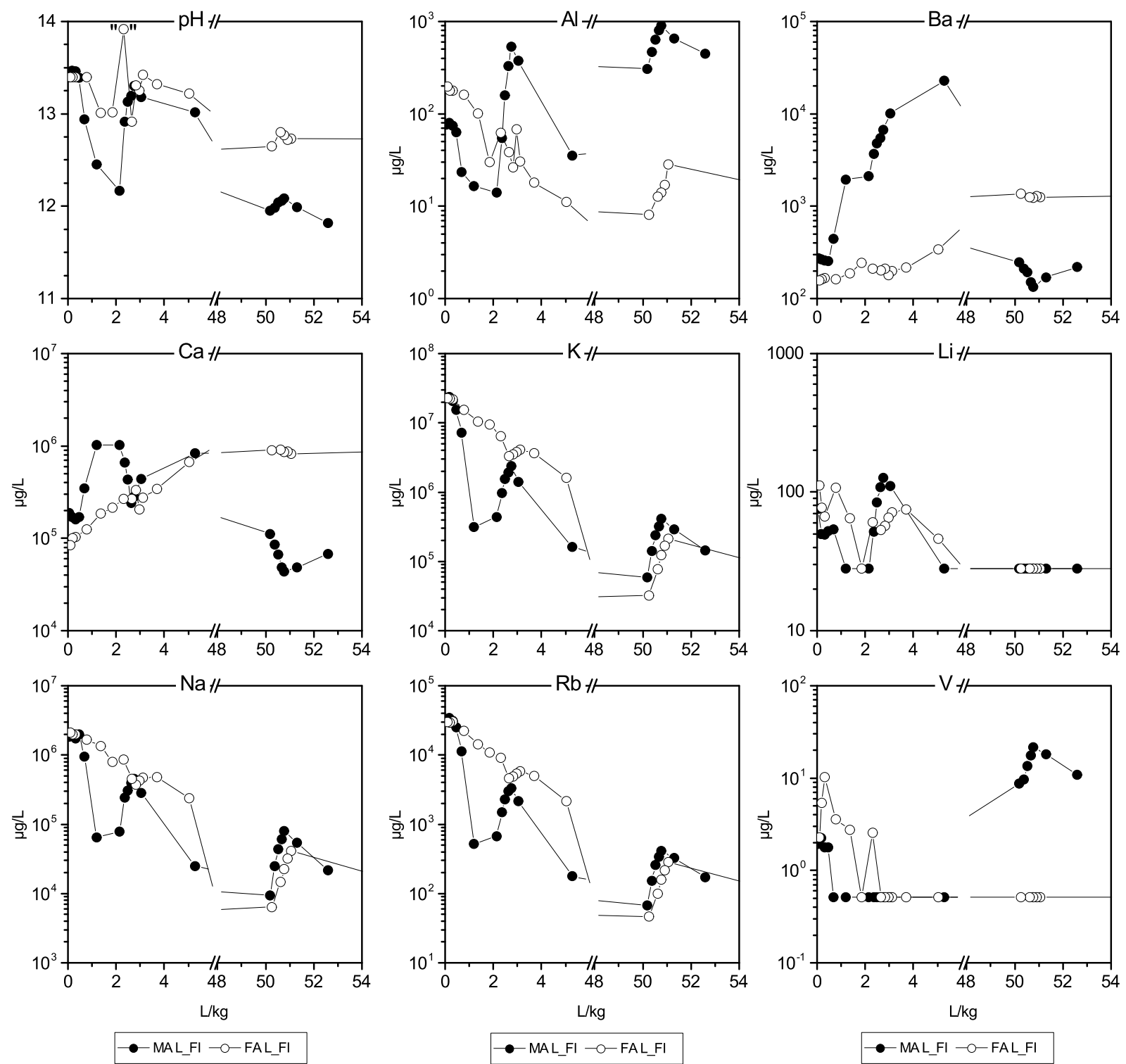

627 Figure 3. Concentration levels of $\mathrm{Al}, \mathrm{Ba}, \mathrm{Ca}, \mathrm{K}$ and $\mathrm{V}$ leachates from interrupted columns (MA-L_FI and FA-L_FI)

628 during the two flow-interruptions at L/S $2 \mathrm{~L} / \mathrm{kg}$ and $50 \mathrm{~L} / \mathrm{kg}$. Results are expressed in $\mu \mathrm{g} / \mathrm{L}$. [-L: long column; _FI:

629 flow-interrupted column; " ": indicates a possible outlier in the pH measurements] 
1. Characterization of wood ash samples .......................... page 2

660

3. Additional Tables and Figures

Figure $\mathbf{S 1}$ ..page 4-5 


\section{Characterisation of wood ash samples}

673 Fresh subsamples of MA and FA were characterised for their moisture content (EN 1097-5:2008) at $110^{\circ} \mathrm{C}$; these dried 674 samples were crushed for the fraction above $4 \mathrm{~mm}$ (jaw crusher), and milled (vibratory disc mill, agate discs). The 675 pulverised samples were then split into subsamples of $0.5 \mathrm{~g}$ for the measurement of the total organic carbon (TOC; EN 676 13137: 2001; LECO induction furnace CS-200 Analyzer), and $0.2 \mathrm{~g}$ for the analysis of S and N (Elemental Analyzer 677 Vario MACRO cube). Additional $0.25 \mathrm{~g}$ of pulverised ashes were acid digested (EN 13656: 2003) in a microwave oven 678 (Multiwave Anton Paar 3000) by using $6 \mathrm{ml}$ of $\mathrm{HNO}_{3}$ (65\%), $2 \mathrm{ml}$ of $\mathrm{HCl}(37 \%), 2 \mathrm{ml}$ of $\mathrm{HF}(40 \%)$ and 12 $\mathrm{H}_{3} \mathrm{BO}_{3}(10 \%) ; 2 \mathrm{ml}$ of $\mathrm{H}_{2} \mathrm{O}_{2}(30 \%)$ were also added to support the oxidation of the residual organic matter. The digested 680 samples were analysed by means of ICP-MS (7700x, Agilent Technologies) for the content of Al, As, Ba, Be, Cd, Co, $681 \mathrm{Cr}, \mathrm{Cu}, \mathrm{Fe}, \mathrm{Li}, \mathrm{Mg}, \mathrm{Mn}, \mathrm{Mo}, \mathrm{Ni}, \mathrm{Pb}, \mathrm{Rb}, \mathrm{Sb}, \mathrm{Se}, \mathrm{Si}, \mathrm{Sn}, \mathrm{Sr}, \mathrm{Tl}, \mathrm{V}$ and $\mathrm{Zn}$, and by ICP-OES (Varian Vista-MPX) 682 for the content of $\mathrm{Ca}, \mathrm{K}, \mathrm{Mn}, \mathrm{Na}$ and $\mathrm{P}$. Subsamples of the dried MA and FA $\left(110^{\circ} \mathrm{C}\right)$ ashes were additionally used for particles size distribution analyses (EN 933-1: 2012) using 13 stainless steel sieves with mesh sizes in the range of $0.063 \mu \mathrm{m}-25 \mathrm{~mm}$.

\section{Estimated pore volume}

Pore volume was estimated as follows:

- Step 1. Fill the column with sand, ash and filters according to EN 14405: 2017; close the column, and weigh it. To 690 - Step 2. Take the column from Step 1 and fill it with water; weigh the column, and subtract the estimated water 691 contained in the sand pore volume.

692 - Step 3. Subtract the result from Step 2 by Step 1. This is the estimated pore volume.

693 The average sand pore volume was determined based on previous tests. 
696 Table S1. List of minerals included in the geochemical model evaluation. The names of the minerals comply with the

697 thermodynamic database used (ORCHESTRA code; Meeussen (2003)).

\begin{tabular}{|c|c|}
\hline MA sample & FA sample \\
\hline AA-3CaO-A12O3[Ca[OH]2]0-5-[CaCO3]0-5-11-5H2O[s].si & $\mathrm{AA}-3 \mathrm{CaO}-\mathrm{Al} 2 \mathrm{O} 3[\mathrm{Ca}[\mathrm{OH}] 2] 0-5-[\mathrm{CaCO} 3] 0-5-11-5 \mathrm{H} 2 \mathrm{O}[\mathrm{s}] . \mathrm{si}$ \\
\hline AA-3CaO-Al2O3-CaCO3-11H2O[s].si & AA-3CaO-A12O3-6H2O[s].si \\
\hline AA-3CaO-Fe2O3[Ca[OH]2]0-5[CaCO3]0-5-11-5H2O[s].si & AA-3CaO-Fe2O3[Ca[OH $] 2] 0-5[\mathrm{CaCO} 3] 0-5-11-5 \mathrm{H} 2 \mathrm{O}[\mathrm{s}] . \mathrm{si}$ \\
\hline AA-3CaO-Fe2O3-6H2O[s].si & AA-3CaO-Fe2O3-6H2O[s].si \\
\hline AA-Brucite.si & AA-3CaO-Fe2O3-CaCO3-11H2O[s].si \\
\hline AA-CO3-hydrotalcite.si & AA-Brucite.si \\
\hline AA-Calcite.si & AA-CO3-hydrotalcite.si \\
\hline AA-Ettringite.si & AA-Calcite.si \\
\hline AA-Fe-Ettringite.si & AA-Ettringite.si \\
\hline $\mathrm{AA}-\mathrm{Fe}[\mathrm{OH}] 3[$ microcr $] . s i$ & AA-Fe-Ettringite.si \\
\hline AA-Jennite.si & $\mathrm{AA}-\mathrm{Fe}[\mathrm{OH}] 3[$ microcr].si \\
\hline AA-Portlandite.si & AA-Jennite.si \\
\hline AA-Tobermorite-I.si & AA-Portlandite.si \\
\hline AA-Tobermorite-II.si & AA-Tobermorite-I.si \\
\hline Aragonite.si & AA-Tobermorite-II.si \\
\hline $\mathrm{BaCaSO} 4[50 \% \mathrm{Ba}] . \mathrm{si}$ & Akerminite.si \\
\hline BaCaSO4[75\%Ba].si & Aragonite.si \\
\hline BaCrO4.si & $\mathrm{BaCaSO} 4[50 \% \mathrm{Ba}] . \mathrm{si}$ \\
\hline $\mathrm{BaSrSO} 4[50 \% \mathrm{Ba}] . \mathrm{si}$ & $\mathrm{BaCaSO} 4[75 \% \mathrm{Ba}] . \mathrm{si}$ \\
\hline $\mathrm{Ba}[\mathrm{SCr}] \mathrm{O} 4[77 \% \mathrm{SO} 4] . \mathrm{si}$ & BaCrO4.si \\
\hline $\mathrm{Ba}[\mathrm{SCr}] \mathrm{O} 4[96 \% \mathrm{SO} 4] . \mathrm{si}$ & $\mathrm{BaSrSO} 4[50 \% \mathrm{Ba}] . \mathrm{si}$ \\
\hline Barite.si & $\mathrm{Ba}[\mathrm{SCr}] \mathrm{O} 4[77 \% \mathrm{SO} 4] . \mathrm{si}$ \\
\hline Birnessite.si & $\mathrm{Ba}[\mathrm{SCr}] \mathrm{O} 4[96 \% \mathrm{SO} 4] . \mathrm{si}$ \\
\hline Brucite.si & Barite.si \\
\hline CSH-ECN.si & Birnessite.si \\
\hline Ca-Olivine.si & Bixbyite.si \\
\hline Ca2V2O7.si & Brucite.si \\
\hline Calcite.si & Bunsenite.si \\
\hline Celestite.si & CSH-ECN.si \\
\hline Clinoenstatite.si & Ca-Olivine.si \\
\hline $\mathrm{Cu}[\mathrm{OH}] 2[\mathrm{~s}] . \mathrm{si}$ & Calcite.si \\
\hline CuprousFerrite.si & Clinoenstatite.si \\
\hline Diaspore.si & $\mathrm{Cu}[\mathrm{OH}] 2[\mathrm{~s}] . \mathrm{si}$ \\
\hline Ettringite.si & CuprousFerrite.si \\
\hline Ettringite-ECN.si & Diaspore.si \\
\hline $\mathrm{Fe}[\mathrm{OH}] 2.7 \mathrm{Cl} 0.3 . \mathrm{si}$ & Ettringite.si \\
\hline Forsterite.si & Ettringite-ECN.si \\
\hline Franklinite.si & $\mathrm{Fe}[\mathrm{OH}] 2.7 \mathrm{Cl} 0.3 . \mathrm{si}$ \\
\hline Goethite.si & Forsterite.si \\
\hline Hilgenstockite.si & Franklinite.si \\
\hline Lepidocrocite.si & Goethite.si \\
\hline Maghemite.si & Hilgenstockite.si \\
\hline Manganite.si & Larnite.si \\
\hline Merwinite.si & Lepidocrocite.si \\
\hline Microcline.si & Maghemite.si \\
\hline Monticellite.si & Manganite.si \\
\hline Montmorillonite.si & Merwinite.si \\
\hline Muscovite.si & Monticellite.si \\
\hline Na-Nontronite.si & $\mathrm{Ni}[\mathrm{OH}] 2[\mathrm{~s}] . \mathrm{si}$ \\
\hline $\mathrm{Ni2SiO} 4 . s i$ & Nsutite.si \\
\hline $\mathrm{Ni}[\mathrm{OH}] 2[\mathrm{~s}] . \mathrm{si}$ & P-Wollstanite.si \\
\hline Nsutite.si & $\mathrm{Pb}[\mathrm{OH}] 2[\mathrm{C}] . \mathrm{si}$ \\
\hline P-Wollstanite.si & Plattnerite.si \\
\hline Portlandite.si & Portlandite.si \\
\hline Quartz.si & Pyrolusite.si \\
\hline Sepiolite[a].si & Quartz.si \\
\hline Sepiolite[c].si & Schoepite.si \\
\hline SrMoO4.si & Sepiolite[a].si \\
\hline Strontianite.si & SrMoO4.si \\
\hline Tenorite.si & Strontianite.si \\
\hline Willemite.si & Tenorite.si \\
\hline Wollastonite.si & Wollastonite.si \\
\hline Zincite.si & Zincite.si \\
\hline ZnSiO3.si & ZnSiO3.si \\
\hline
\end{tabular}



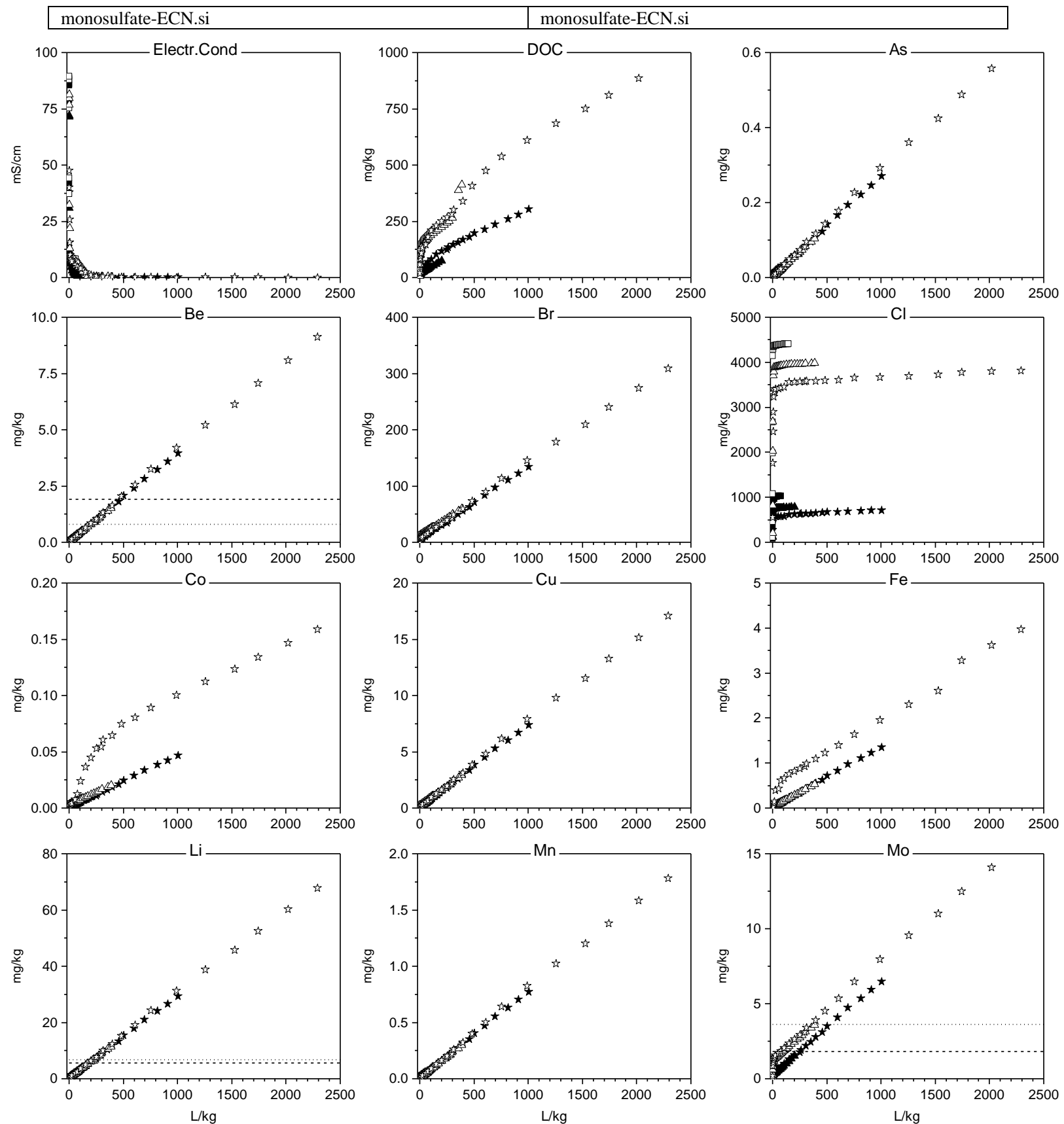

$$
\begin{aligned}
& \text { - MAL \ MAM « MAS } \\
& \text { 口 FAL } \triangle F A M \text { \& } F A S \\
& \text {.... MA tot...... FA tot }
\end{aligned}
$$

$$
\begin{aligned}
& \hline \text { - MAL } \Delta \text { MAM } \star \text { MAS } \\
& \square F A L \triangle F A M \text { \& FAS } \\
& \cdots \text { MA tot …... FA tot } \\
& \hline
\end{aligned}
$$

699 Figure S1a. Cumulative release of $\mathrm{As}, \mathrm{Be}, \mathrm{Br}, \mathrm{Cl}, \mathrm{Co}, \mathrm{Cu}, \mathrm{Fe}, \mathrm{Li}, \mathrm{Mn}, \mathrm{Mo}$, dissolved organic carbon (DOC) and

700 electrical conductivity from continuous MA and FA columns. Results are expressed in mg/kg, except for the electrical

701 conductivity (mS/cm). [-L: long column; -M: medium column; -S: short column].

(Figure S1 continues on the next page) 

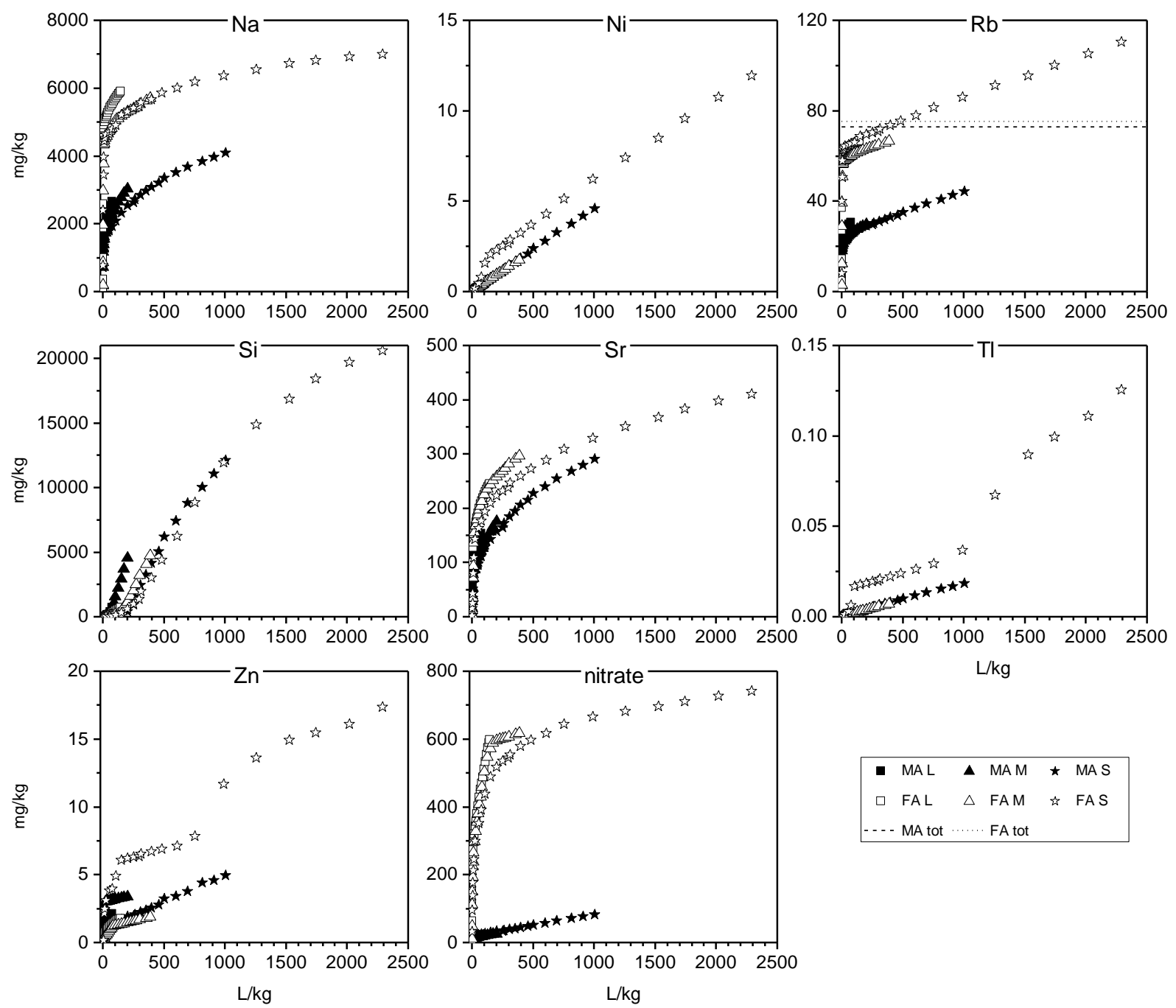

L/kg

Figure S1b. (continuation) Cumulative release of $\mathrm{Na}, \mathrm{Ni}, \mathrm{Rb}, \mathrm{Si}, \mathrm{Sr}, \mathrm{Tl}, \mathrm{Zn}$ and nitrate from continuous MA and $\mathrm{FA}$ columns. Results are expressed in mg/kg. [-L: long column; -M: medium column; -S: short column]. 

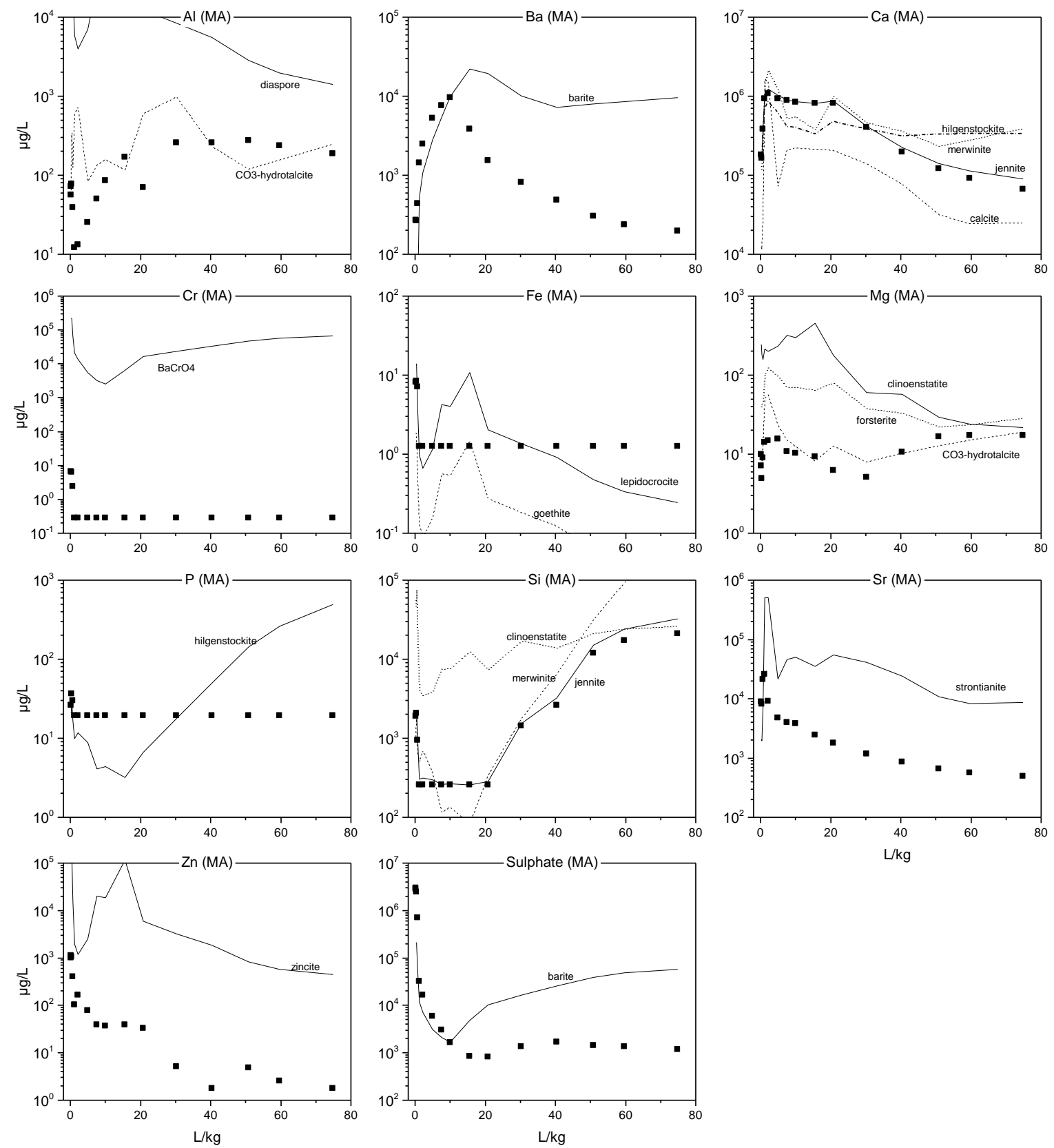

710 Figure S2. Speciation model results in comparison with the observed concentrations for $\mathrm{Al}, \mathrm{Ba}, \mathrm{Ca}, \mathrm{Cr}, \mathrm{fe}, \mathrm{Mg}, \mathrm{P}, \mathrm{Si}$,

$711 \mathrm{Sr}, \mathrm{Zn}$ and sulphate in the leachates from MA-L columns. 

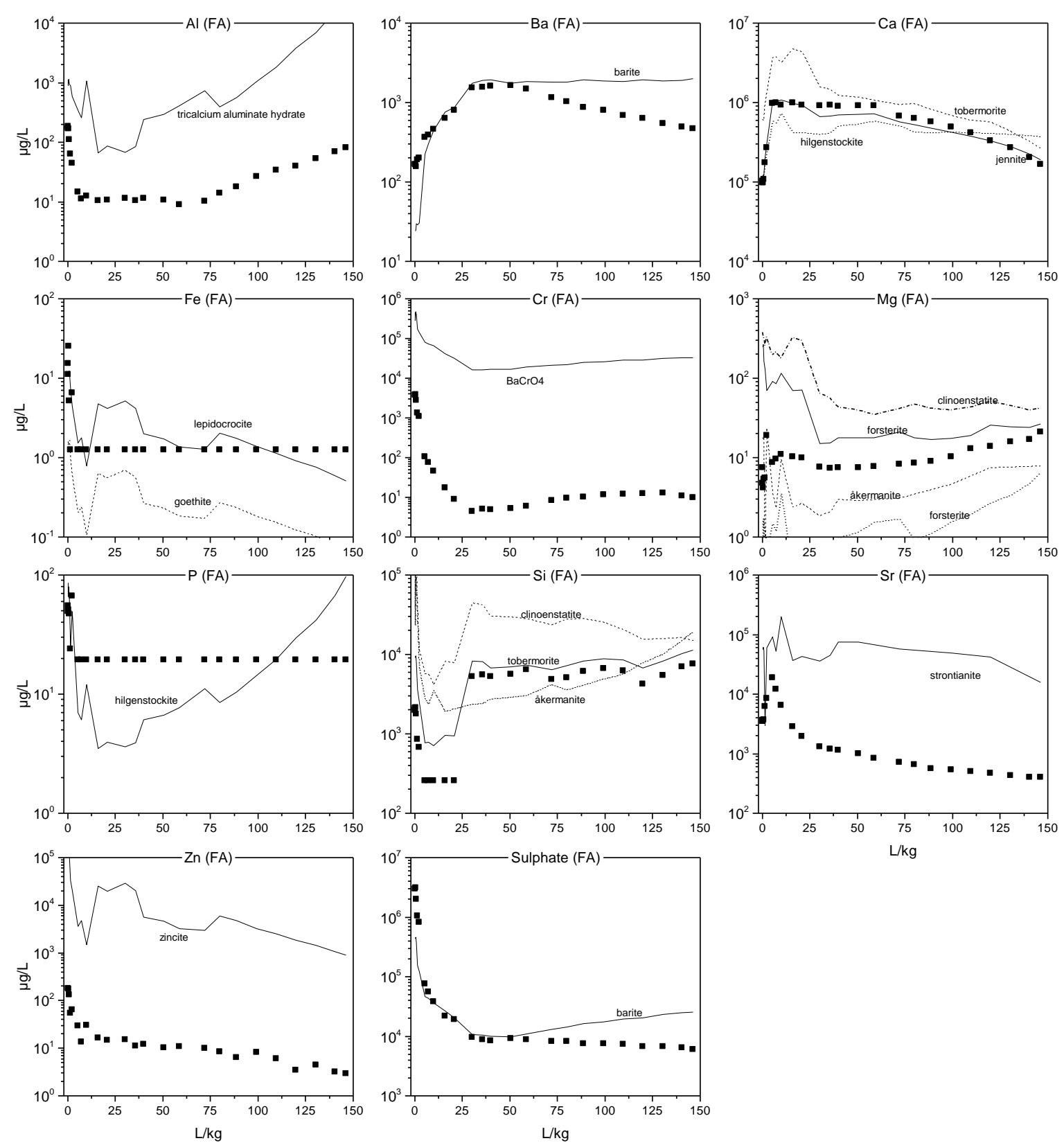

714 Figure S3. Speciation model results in comparison with the observed concentrations for $\mathrm{Al}, \mathrm{Ba}, \mathrm{Ca}, \mathrm{Cr}, \mathrm{fe}, \mathrm{Mg}, \mathrm{P}, \mathrm{Si}$,

$715 \mathrm{Sr}, \mathrm{Zn}$ and sulphate in the leachates from FA-L columns. 

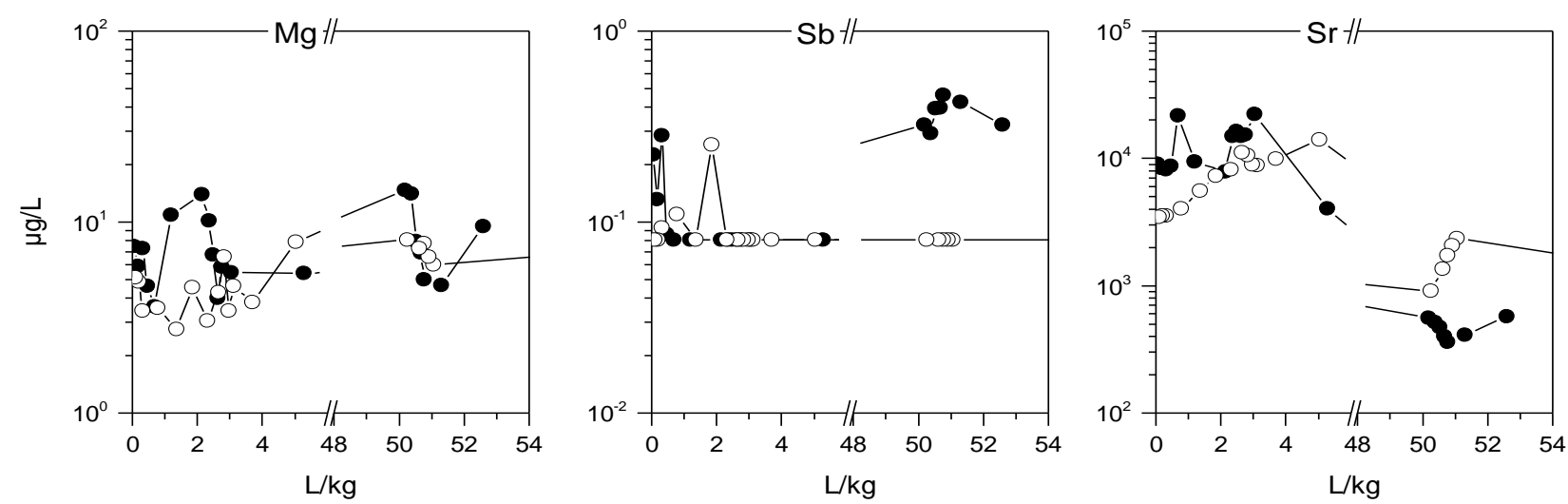

717 Figure S4. Concentration levels of $\mathrm{Mg}, \mathrm{Sb}$ and $\mathrm{Sr}$ in the leachates from interrupted columns (MA-L_FI and FA-L_FI)

during the two flow-interruptions at L/S $2 \mathrm{~L} / \mathrm{kg}$ and $50 \mathrm{~L} / \mathrm{kg}$. Results are expressed in $\mu \mathrm{g} / \mathrm{L}$.

\section{REFERENCES}

DS/EN 13656:2003. Characterisation of waste - microwave assisted digestion with hydrofluoric (HF), nitric (HNO3) and hydrochloric $(\mathrm{HCl})$ acid mixture for subsequent determination of elements.

EN 1097-5:2008. Tests for mechanical and physical properties of aggregates - Part 5: Determination of the water content by drying in a ventilated oven.

EN 13137:2001. Characterization of waste - Determination of total organic carbon (TOC) in waste, sludges and sediments.

EN 14405:2017. Dansk standard Karakterisering af affald - Test af udvaskningsegenskaber - Opstrøms perkolationstest (under fastlagte betingelser). Characterization of waste - Leaching behaviour test - Up-flow percolation test (under specified conditions).

EN 933-1, 2012. Tests for geometrical properties of aggregates - Part 1: Determination of particle size distribution Sieving method. Models. Environ. Sci. Technol. 37, 1175-1182. doi:10.1021/es025597s 